\title{
Late Pleistocene to Holocene climate and limnological changes at Lake Karakul (Pamir Mountains, Tajikistan)
}

Liv Heinecke ${ }^{1,2}$, Steffen Mischke ${ }^{3}$, Karsten Adler², Anja Barth ${ }^{4}$, Boris K. Biskaborn ${ }^{1}$, Birgit Plessen ${ }^{5}$, 5 Ingmar Nitze ${ }^{1}$, Gerhard Kuhn ${ }^{6}$, Ilhomjon Rajabov ${ }^{7}$, Ulrike Herzschuh ${ }^{1,2}$

${ }^{1}$ Alfred Wegener Institute Helmholtz Centre for Polar and Marine Research, Research Unit Potsdam, Telegrafenberg A43, 14473 Potsdam, Germany

${ }^{2}$ Institute of Earth and Environmental Science, University of Potsdam, Karl-Liebknecht-Str. 24-25, 14476 Potsdam-Golm, Germany

$10 \quad{ }^{3}$ Faculty of Earth Sciences, University of Iceland, Sturlugata 7, Askja, 101 Reykjavík, Iceland

${ }_{5}^{4}$ Institute of Geological Sciences, Free University of Berlin, Malteserstr. 74-100; 12249 Berlin, Germany

${ }^{5}$ Helmholtz Centre Potsdam, GFZ German Research Centre for Geosciences, Sektion 5.2, Telegrafenberg C327, 14473 Potsdam, Germany

${ }^{6}$ Alfred Wegener Institute Helmholtz Centre for Polar and Marine Research, Am Alten Hafen 26, 27568 Bremerhaven, 15 Germany

${ }^{7}$ Pilot Program for Climate Resilience Secretariat, Shevchenko Street 47, Dushanbe, Tajikistan

Correspondence to: Liv Heinecke (liv.heinecke@awi.de)

Abstract. Lake Karakul, located in the eastern Pamir Mountains, Tajikistan, is today dominated by the Westerlies. It is a matter of debate whether the Indian Monsoon influenced the region in the past. We analysed an $11.25 \mathrm{~m}$ sediment core covering the last 29,000 years to assess and separate lake-internal and lake-external processes, and to infer changes in the predominant atmospheric circulation. Among the parameters indicating lake-external processes, high values in grain-size end-member (EM) 3 (wide grain-size distribution, marking fluvial input) and $\mathrm{Sr} / \mathrm{Rb}$ and $\mathrm{Zr} / \mathrm{Rb}$ ratios (coinciding with coarse grain sizes, implying increased physical weathering) are interpreted as a strong monsoonal impact. High values in EM1, EM2 (peaking at small grain sizes reflecting Westerlies-derived dust) and $\mathrm{TiO}_{2}$ (terrigenous input) are assumed to reflect a strong influence of Westerlies. High input of far-transported dust from the pre- Last Glacial Maximum (LGM) to the late glacial reflects the Westerlies influence, while peaks in fluvial input suggest monsoonal influence. The early to early-mid Holocene is characterised by coarse mean grain sizes, increased physical weathering and constantly high fluvial input indicating a strengthened Indian Monsoon that reached further north into the Karakul region. A steady increase in terrigenous dust, decrease in fluvial input and physical weathering from $6.7 \mathrm{cal} \mathrm{kyr}$ BP onwards signals that Westerlies

30 became the predominant atmospheric circulation and brought an arid climate to the region. Proxies for productivity (TOC, $\mathrm{C} / \mathrm{N}, \mathrm{TOC}_{B r}$ ), redox potential $(\mathrm{Fe} / \mathrm{Mn})$ and changes in the endogenic carbonate precipitation (TIC) indicate lake-internal changes. Low productivity characterised the lake from the late Pleistocene until $6.7 \mathrm{cal}$ kyr BP and rapidly increased afterwards. The lake level remained low until the LGM, but water depth increased during the late glacial, reaching a high- 
Clim. Past Discuss., doi:10.5194/cp-2016-34, 2016

Manuscript under review for journal Clim. Past

Published: 7 April 2016

(c) Author(s) 2016. CC-BY 3.0 License.

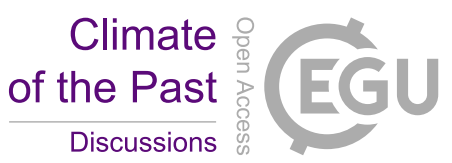

stand during the early Holocene. Subsequently, the water level decreased until its present state. Today the lake system is mainly climatically controlled but the depositional regime is also driven by lake-internal limnogeological processes.

\section{Introduction}

Interactions between the atmosphere and terrestrial environments have increasingly become the focus of research since recent climate change has become an acknowledged issue (Pachauri et al., 2014; Pielke et al., 1998; Williamson et al., 2008). In semi-arid and arid mountain regions, the interactions between climate, glacial dynamics, water capacity of mountain lakes and, in consequence, their influence on river water discharge need to be understood. The high mountain ranges of Central Asia are of particular interest within this context due to the complexity of the regional circulation mechanisms (Aizen et al., 2001; Chen et al., 2010; Ramaswamy, 1962), the steep environmental gradients originating from the pronounced relief, and especially the many large rivers originating in this region and supplying water to densely-populated mountain forelands in India, China and Inner Asia. Therefore, our understanding of linkages between atmosphere and terrestrial environments should not only be based on observation alone but, as long-term processes are involved, rooted in palaeoenvironmental reconstructions.

Central Asia is located in the transition zone between the Westerlies and the monsoon system (Holmes et al., 2009; Wang et

15 al., 2010). The interplay of these climate systems in the past has been the focus of several studies of decadal (e.g. Loader et al., 2010), centennial (e.g. Aizen et al., 2001) and millennial scale climate records (e.g. Herzschuh, 2006; Holmes et al., 2009; Sato, 2009).

A speleothem study covering the last $500 \mathrm{kyr}$, revealed that Central Asia was not only influenced by the Westerlies, but also by the Asian Monsoon during warm periods (Cheng et al., 2012). These results are in agreement with reconstructions of the

20 glaciation history in the Central Asian mountain ranges during the late Pleistocene and Holocene (Abramowski et al., 2006; Dortch et al., 2013; Owen and Dortch, 2014; Seong et al., 2009). However, studies focusing on the mid- and late Holocene show a more distinct Westerlies influence in the Pamir (Lei et al., (2014) and the Tian Shan Mountains (Lauterbach et al., 2014).

Generally, lake sediments provide valuable palaeoclimate information. Most of the respective Central Asian studies are 25 either located on the Tibetan Plateau, in lower to moderate mountain areas of western Central Asia, or in bordering basins (Van Campo and Gasse, 1993; Ji et al., 2005; Kramer et al., 2010; Opitz et al., 2012; Gebhardt et al., 2016), but literature research showed that studies from high mountain regions, like the Pamir, are rare. Available studies focus on glacial activity (e.g. Abramowski et al., 2006; Liu et al., 2014; Zech et al., 2005), fluvial system development and climatic-tectonic interactions (Fuchs et al., 2014, 2015). It is still unclear whether large and deep lakes in mountainous environments react 30 directly to climate or with some delay, or whether they are mainly internally driven and thus inert to climate change (Williamson et al., 2008). Signals reflecting changes in the stratification of lakes or ice-cover duration are stored in the sediments (Birks and Birks, 1980). Various sedimentary parameters provide proxy information on changes in 
Clim. Past Discuss., doi:10.5194/cp-2016-34, 2016

Manuscript under review for journal Clim. Past

Published: 7 April 2016

(c) Author(s) 2016. CC-BY 3.0 License.

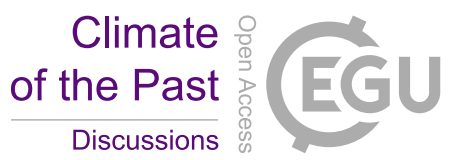

bioproductivity, water chemistry and lake level (e.g. Hudson and Quade, 2013; Lister et al., 1991) and thus portray the lake's relationship with climate.

Here we present a sedimentary record from Lake Karakul (3929 m asl) located in the eastern Pamir, Tajikistan, dating back $29 \mathrm{cal} \mathrm{kyr} \mathrm{BP.} \mathrm{Our} \mathrm{first} \mathrm{objective} \mathrm{is} \mathrm{to} \mathrm{separate} \mathrm{sedimentary} \mathrm{geochemical} \mathrm{data} \mathrm{into} \mathrm{proxies} \mathrm{for} \mathrm{lake-internal} \mathrm{conditions} \mathrm{and}$

5 those for lake-external climate change, and assess their reliability. Second, we aim to reconstruct climate changes and, by comparison with other records, we attempt to assign the inferred trends to changes in the dominant atmospheric circulation systems. Third, we hope to show whether lake-internal changes are driven by or are separate from regional climate change.

\section{Study site}

Lake Karakul (Tajik for 'black lake') is located in the north-east of the autonomous region Gorno-Badakhshan (e.g. Lister et 10 al., 1991) of Tajikistan, in the eastern Pamir Mountains (Fig.1), which are adjoined by the Hindukush and Karakorum in the south and the Tian-Shan in the north. The Karakul Basin is a 50km wide depression located in a complex tectonic setting, formed by a number of faults (Strecker et al., 1995) and resulting in an asymmetric graben (Nöth et al., 1932; Ergashev, 1979; Melack, 1983). The surrounding mountain ranges, which mainly consist of Palaeozoic metasediments and Triassic granites (Nöth et al., 1932; Melack, 1983), reach heights of $5000 \mathrm{~m}$ above sea level (asl) with single peaks reaching over

$156000 \mathrm{~m}$ asl in the catchment of the lake. Quaternary lacustrine and glacial deposits fill the basin as a result of presumably multiple, but a minimum of two, glaciations (Komatsu, 2009, 2010). Two horst structures form an island and a peninsula in the centre of the basin which divide the lake into a deeper western and a shallower eastern sub-basin. The greater water depth (>240 m) of the western sub-basin originates from pronounced tectonic subsidence rather than sediment starvation (Strecker et al., 1995).

20 The modern lake is brackish with a pH of 9.2 (Mischke et al., 2010a) and the endorheic basin is mainly supplied with freshwater originating from the surrounding glaciers, snow fields and frozen ground (Mischke et al., 2010a), while direct discharge from precipitation in the catchment area is of minor importance (Ni et al., 2004). Precipitation is generally low with an annual mean of $82 \mathrm{~mm}$, but characterized by high variability. The Westerlies, which are the main moisture source (Böhner, 2006), are blocked by the mountain ranges to the west of the lake. Air temperature in the region is low due to the

25 high elevation. The meteorological station at Lake Karakul recorded a mean annual temperature of $-3.9^{\circ} \mathrm{C}$, with a mean January temperature of $-18.1^{\circ} \mathrm{C}$ and a mean July temperature of $8.5^{\circ} \mathrm{C}$ (measuring period 1933 to 2007, excl. 1995-2003). Low winter temperatures cause ice cover from November until May with up to one metre of ice thickness. A maximum Secchi depth of $19 \mathrm{~m}$ was recorded during the open-water season (Ergashev, 1979), while depths of 10.7-11.7 m were recorded in June 2008 (Mischke et al., 2010a) and only $3.4 \mathrm{~m}$ in August 2013. Potamogeton pamiricus and Characeae 30 colonize the littoral zone (Hammer, 1986). The terrestrial vegetation in the catchment is dominated by alpine steppe vegetation taxa, such as Stipa, Oxytropis and Artemisia, which have a higher cover in close vicinity to the shoreline, near fluvial inlets and on alluvial plains (Mischke et al., 2010b; and personal observations). The lake is not used for fishing. 
Clim. Past Discuss., doi:10.5194/cp-2016-34, 2016

Manuscript under review for journal Clim. Past

Published: 7 April 2016

(c) Author(s) 2016. CC-BY 3.0 License.

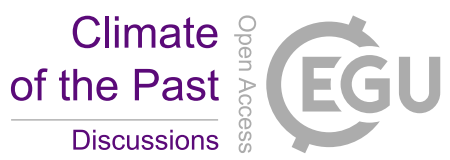

(c) (i)

Grazing occurs in the catchment of the lake and bushes are removed for the production of fire materials. Otherwise, direct human impact on the lake and its catchment is very low.

\section{Materials and methods}

\subsection{Fieldwork}

5 The core KK12-1 (composite length $11.25 \mathrm{~m}$ ) was collected during a field campaign in spring 2012 using UWITEC coring equipment ("Niederreiter 60") at a water depth of $12 \mathrm{~m}$ operated on the ice cover of Lake Karakul (core site coordinates: $39.0176^{\circ} \mathrm{N}, 73.5327^{\circ} \mathrm{E}$; Fig.1.). Coring at a more central position in the eastern sub-basin was impossible due to thin ice cover and the onset of ice breakup in April 2012. Due to the same reason, coring was conducted from a single ice hole without overlapping of sediment core segments. Hence, small gaps occur between each $2 \mathrm{~m}$ core segment because of the

10 piston in the coring liner. Sediment between 525 and $568 \mathrm{~cm}$ composite depth was lost during coring. A second parallel core (KK12-2) was recovered from a position $10 \mathrm{~m}$ away, due to time and financial limitations, these sediments were not investigated.

The cores were transported to the Alfred Wegener Institute, Helmholtz Centre for Polar and Marine Research (AWI) in Potsdam and stored in the original $6 \mathrm{~cm}$ diameter PVC coring tubes at $4^{\circ} \mathrm{C}$ after being split into $1 \mathrm{~m}$ segments.

15 Nine additional sediment samples collected from different modern depositional settings (e.g. slackwater, pond, dry river channel, sand dune; see supplement) in the eastern to northern vicinity of the lake were analysed as reference materials.

\subsection{Laboratory analysis}

\subsubsection{Core sampling and dating}

Sediment core segments were split into two halves along the long axis. The "archive" halves were used for smear slide analysis and non-destructive work such as initial core description and X-ray fluorescence (XRF) scanning. The "work" halves were subsampled for radiocarbon dating and sedimentological analyses (e.g. CNS, TOC, grain-size distribution).

Fourteen samples, comprising nine plant remains, four bulk sediment samples and one sample of an in-situ living charophyte, were dated at the Poznań Radiocarbon Laboratory, Poland (Table 1). Radiocarbon ages were corrected for the 'lake reservoir effect' of Lake Karakul based on the published lake reservoir effect of and the apparent age of the newly collected macro-algae from core KK12-10 (Mischke et al., 2010b). The charophyte species revealed a $\mathrm{F}^{14} \mathrm{C}$ (modern fraction; Reimer et al., 2004) of 0.8914, which is equivalent to a lake reservoir effect of 1315 years. An average of both determined lake reservoir effects of 1368 years was applied as a correction to the original radiocarbon age data assuming that the lake reservoir effect did not change through time. The mean lake reservoir effect of 1368 years was used in the age-depth model (Fig.2) created using the Bacon package (Blaauw and Christen, 2011) in R (R Core Team, 2012) and is calibrated to calendar 
Clim. Past Discuss., doi:10.5194/cp-2016-34, 2016

Manuscript under review for journal Clim. Past

Published: 7 April 2016

(c) Author(s) 2016. CC-BY 3.0 License.

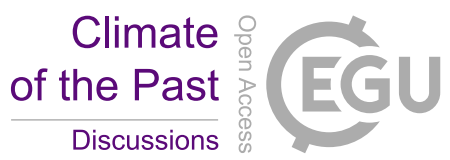

(c) (i)

years using the IntCal13 calibration curve (Reimer et al., 2013). The Bacon parameter settings largely follow Blaauw and Christen (2011), but with mean accumulation set to $20\left(\mathrm{yr} \mathrm{cm}^{-1}\right)$, and memory strength set to 20 to account for bioturbation effects originating from dense macrophyte cover. The obtained age-depth models were fairly robust to variations in the parameter settings.

5 The uppermost dated sediment sample from KK12-1 was excluded from the age-depth model as the sediment was probably deposited during and after the nuclear bomb testing period with highly variable $\mathrm{F}^{14} \mathrm{C}$ values (Reimer et al., 2004). Nevertheless, the lake-reservoir effect corrected and calibrated age for this sample fits reasonably well with the established age-depth model.

\subsubsection{Sedimentology}

10 Smear slides were prepared and inspected approximately every $40 \mathrm{~cm}$. Total carbon (TC), total nitrogen (TN), total sulphur (TS), total organic carbon (TOC) and the grain-size distribution were analysed for 97 samples taken at $10 \mathrm{~cm}$ intervals. The freeze-dried and finely ground samples for elementary analyses were weighed into tin capsules for CNS analyses and measured using an Elementar vario EL III (CNS) analyser. An Elementar vario MAX C was used to quantify TOC. TN values in the lower part of the core were in occasionally at or close to the detection limit at $0.1 \%$, however the data were

15 used to calculate TOC/TN ratios following Meyers and Teranes (2002). Total inorganic carbon (TIC) was calculated by deducting TOC from TC values.

Stable isotope analyses on authigenic carbonat were conducted on 98 samples spaced approximately every $10 \mathrm{~cm}$. The samples were bleached for $24 \mathrm{~h}$ with $2.5 \% \mathrm{NaOCl}$ to remove the organic content and sieved with a $36 \mu \mathrm{m}$ mesh to clean the samples of detrital components and shells. The remaining authigenic carbonate fraction was freeze-dried, ground for

20 homogenization and loaded into Labco vialstin capsules. Measurements of $\delta^{13} \mathrm{C}_{\text {AuthCarb }}$ (AuthCarb = authigenic carbonate) and $\delta^{18} \mathrm{O}_{\text {AuthCarb }}$ were undertaken with a ThermoFinnigan Gasbench II linked to a DELTA ${ }^{\text {plus }}$ XL mass spectrometer and measured after digestion with $103 \% \mathrm{H}_{3} \mathrm{PO}_{4}$ at $72^{\circ} \mathrm{C}$ for $60 \mathrm{~min}$ at the German GeoForschungsZentrum (GFZ) in Potsdam. The stable isotope data are reported in per mil relative to VPDB and calibrated using NBS19 with an analytic precision error of $<0.08 \%$ for both $\delta^{13} \mathrm{C}_{\text {AuthCarb }}$ and $\delta^{18} \mathrm{O}_{\text {AuthCarb }}$ on reference material.

\section{$25 \quad$ 3.2.3 Grain-size analysis}

Sample preparation for grain-size analysis included $24 \mathrm{~h}$ treatment with $\mathrm{CH}_{3} \mathrm{COOH}$ (10 \%) to remove carbonate, sieving with a $2 \mathrm{~mm}$ sieve to remove abundant plant remains in most parts of the core, and shaking the samples on a platform shaker in initially $0.3 \% \mathrm{H}_{2} \mathrm{O}_{2}$ solution with an addition of $10 \mathrm{ml}$ of $\mathrm{H}_{2} \mathrm{O}_{2}(35 \%)$ every second day for up to six weeks in order to remove the remaining organic matter. Grain-size analysis was performed with a Coulter LS 200 Laser Diffraction Particle

30 Analyser, which was equipped with a $1 \mathrm{~mm}$ sieve to protect the lens. At least two subsamples were measured for every sample. 
Clim. Past Discuss., doi:10.5194/cp-2016-34, 2016

Manuscript under review for journal Clim. Past

Published: 7 April 2016

(c) Author(s) 2016. CC-BY 3.0 License.

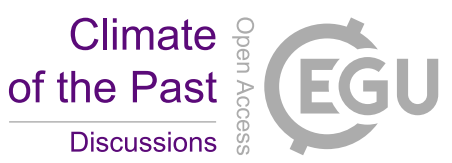

\subsubsection{XRF analysis}

High-resolution non-destructive XRF measurements were performed with an Avaatech XRF Core Scanner at AWI Bremerhaven. After levelling and cleaning the core surface, the sediment core halves were covered with a $4 \mu \mathrm{m}$ transparent film (Ultralene, USA). X-ray voltage of $10 \mathrm{kV}$ for major elements and $30 \mathrm{kV}$ for minor elements with a Rh X-ray tube at 1

$5 \mathrm{~mA}$ was applied at $2 \mathrm{~mm}$ resolution. Element signals were measured in counts per second, converted to XRF peak area intensities and averaged over each $\mathrm{cm}$ after outliers were eliminated. Due to high mean errors expressed as chi squared $\left(\chi^{2}\right)$, probably originating from the high content of plant remains and related air pockets, only results of elements with a reasonable low $\chi^{2}$ were included in the interpretation: Ti (mean $\chi^{2} 3.7$ ), Mn (mean $\chi^{2} 3.8$ ), $\mathrm{Fe}$ (mean $\left.\chi^{2} 10.4\right), \mathrm{Br}$ (mean $\chi^{2}$ 0.8 ), $\mathrm{Zr}$ (mean $\chi^{2} 0.8$ ), $\mathrm{Rb}$ (mean $\chi^{2} 0.7$ ) and $\mathrm{Sr}$ (mean $\chi^{2} 1.1$ ). ). High $\chi^{2}$ for Fe was considered as acceptable if applied in the

$10 \mathrm{Fe} / \mathrm{Mn}$ XRF ratio showing a reasonable trend of the data along the core. To calibrate the XRF scanner data, 26 samples at 30-40 cm intervals from the core KK12-1 were freeze-dried, ground, melted into tablets and analysed with XRF using a PANalytial Axios WDXRF (1 kW) spectrometer at AWI Bremerhaven. Runs were performed once with WROXI standards and once without in the OMNIAN modus to cover the major and some minor elements, and data recorded as oxides. The single sample measurements were used to determine linear regressions in cross plots in order to calculate percentage values

15 from scanner data (see supplement). XRF count ratios were generated directly from the XRF scanner data. Due to good correlation between TOC and XRF $\mathrm{Br}$, we quantified $\mathrm{TOC}_{B r}$ from the peak area intensities of $\mathrm{Br}$ as a high-resolution proxy for the organic carbon content.

\subsubsection{Multivariate statistics}

Different transport and deposition processes can be deciphered from grain-size distribution data using end-member 20 modelling analyses (EMMA; Weltje, 1997). The obtained grain-size data were analysed with the EMMAgeo package (Dietze and Dietze, 2013) in R (R Core Team, 2012). In order to achieve the best fit between modelled and measured data, we performed several model runs with different percentiles (P3/P97, P4/P96, P5/P95, P6/P94, P7.5/P92.5 and P10/P90) (see supplement). The minimum number of potential end-members was determined by the cumulative explained variance that explained $95 \%$ of the total variance of the original grain-size data, while the maximum number of potential end-members was determined by the mean coefficient of determination which reflects the explained variance (mean $r^{2}$ ). To avoid overfitting, a model with P3/P97 and four robust and one residual EM, representing the unexplained variance, was used.

A number of statistical analyses were applied in order to portray the main structure in the data set such as the relationship among the single variables, and between variables and samples. The obtained proxies were separated into lake-internal and lake-external parameters in order to decipher and explain the recorded signals. Principal component analyses (PCA) were

30 applied after the data were square-root transformed, centred and standardized in CANOCO Version 5 (Braak and Šmilauer, 2012). A stratigraphically constrained incremental sum of squares analysis (CONISS) in Tilia version 1.7.16 was applied to the square-root transformed data to identify significant changes in the data and assign zones (Grimm, 1987). 
Clim. Past Discuss., doi:10.5194/cp-2016-34, 2016

Manuscript under review for journal Clim. Past

Published: 7 April 2016

(c) Author(s) 2016. CC-BY 3.0 License.

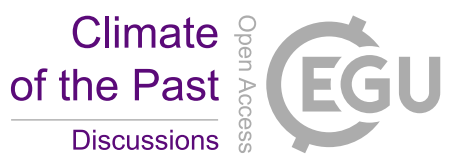

(c) (i)

\section{Results}

\subsection{Age-depth relationship of core KK12-1 from Lake Karakul}

A 'lake-reservoir effect' of 1368 yrs was determined using two in-situ collected living charophytes. The results of the lake reservoir-effect corrected and calibrated samples (Table 1) and the age-depth model (Fig.2) show an approximate age of 29

5 cal kyr BP at the base of core KK12-1. The sediment accumulation rate ranges from $0.15 \mathrm{~mm} \mathrm{yr}^{-1}$ in the lower part of the core to $0.84 \mathrm{~mm} \mathrm{yr}^{-1}$ at the top.

\subsection{TIC, TOC, C/N, $\delta^{18} \mathrm{O}_{\text {AuthCarb }}$ and $\delta^{13} \mathrm{C}_{\text {AuthCarb }}$}

The core KK12-1 consists of a sequence of fine-grained, greyish sediment with a variable amount of plant remains. Plant remains are absent at the base of the core (1087-1012 cm; 28.6-26.5 cal kyr BP), rare in the lower part (1012-725 cm; 26.5 -

$1019.1 \mathrm{cal}$ kyr BP), absent in the middle part (698-464 cm; 17.4-6.9 cal kyr BP) and abundant in the upper part (464-0 cm; 6.9 cal kyr BP to present).

TIC ranges between 1.7 and $8.6 \%$ (median: $3.0 \%$ ) (Fig.3B) and is generally characterized by a high sample-to-sample variation. Lowest values occur between 982 and $692 \mathrm{~cm}$ (26.3 and $17 \mathrm{cal} \mathrm{kyr}$ BP) and the highest values between 682 and $402 \mathrm{~cm}$ (16.5 and $5.3 \mathrm{cal} \mathrm{kyr}$ BP).

15 TOC ranges from $0.1 \%$ to $2 \%$ from the base at $1082 \mathrm{~cm}(28.5 \mathrm{cal} \mathrm{kyr} \mathrm{BP})$ to $452 \mathrm{~cm}$ (6.6 cal kyr BP), followed by a sharp increase with values reaching up to $5.3 \%$ in the upper part of the core and an overall median of $1.6 \%$.

TOC/TN ratios display low values. Results from below $692 \mathrm{~cm}$ (17 cal kyr BP) are rather unreliable because TN was close to detection limit. The highest values were determined between the two maxima both 17.1 at $332 \mathrm{~cm}$ and $172 \mathrm{~cm}(4.1$ and 2.0 cal kyr BP) (Fig.3B).

20 Values of $\delta^{13} \mathrm{C}_{\text {AuthCarb }}$ vary between 1.4 and $4.9 \%$ (median: $3.74 \%$ ). $\delta^{18} \mathrm{O}_{\text {AuthCarb }}$ displays values from -7.4 to $-0.3 \%$ (median: -3.1\%o). Both stable isotope datasets show similar trends over the core with high values from core base until $1025 \mathrm{~cm}$ (28.6 to $26.5 \mathrm{cal} \mathrm{kyr} \mathrm{BP})$, a rapid decrease with generally lower values until $652 \mathrm{~cm}$ (14.7 cal kyr BP), a period of higher values until $292 \mathrm{~cm}$ (3.5 cal kyr BP) and a decreasing trend up to the core top (present day; Fig.3A).

\subsection{Grain-size distribution and results of endmember modelling}

25 Mean grain-size varies mainly between 7 and $31 \mu \mathrm{m}$ (median: $12 \mu \mathrm{m}$ ). A slight mean grain-size decreasing trend and generally less variation were identified in the upper $500 \mathrm{~cm}(<8.1 \mathrm{cal} \mathrm{kyr} \mathrm{BP})$. The final endmember model (P3/P97) results in four robust EMs and one residual EM (Fig.4B). All four EMs show bimodal or polymodal grain-size frequency distribution curves with the main peak at 2-4 $\mu \mathrm{m}$ for EM1, 10-20 $\mu \mathrm{m}$ for EM2, 20-50 $\mu \mathrm{m}$ for EM3 and 100-300 $\mu \mathrm{m}$ for EM4. EM1 accounts for $15.2 \%$ of the detrital sediments over the core, EM2 for $30.1 \%$, EM3 for $18.5 \%$ and EM4 for 35.6

$30 \%$. EM1 and EM2 have relatively high abundances throughout the core, whereas EM3 and EM4 show larger fluctuations 
Clim. Past Discuss., doi:10.5194/cp-2016-34, 2016

Manuscript under review for journal Clim. Past

Published: 7 April 2016

(c) Author(s) 2016. CC-BY 3.0 License.

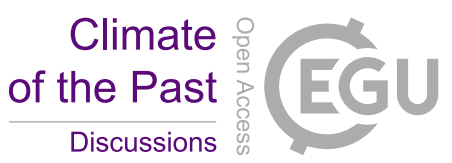

(Fig.3A). The very fine-grained EM1 reaches its highest values up to $67 \%$ between 672 and $622 \mathrm{~cm}(15.8$ and $13.6 \mathrm{cal} \mathrm{kyr}$ BP). EM2 is most abundant from 982 to $942 \mathrm{~cm}$ (25.8 to $25.0 \mathrm{cal} \mathrm{kyr}$ BP) with a maximum of $78 \%$, and between 772 and $732 \mathrm{~cm}$ (21.0 to $19.5 \mathrm{cal} \mathrm{kyr} \mathrm{BP})$ with a maximum of $76 \%$. It is constantly recorded in medium to high proportions (>25\%) from $492 \mathrm{~cm}$ upward ( $8 \mathrm{cal} \mathrm{kyr} \mathrm{BP} \mathrm{until} \mathrm{present).} \mathrm{EM3} \mathrm{shows} \mathrm{peaks} \mathrm{of} 61 \%$ at $832 \mathrm{~cm}(22.7 \mathrm{cal} \mathrm{kyr} \mathrm{BP}), 60 \%$ at $452 \mathrm{~cm}$

5 (6.6 cal kyr BP) and $65 \%$ at $72 \mathrm{~cm}(0.8 \mathrm{cal} \mathrm{kyr} \mathrm{BP})$. Peaks for EM4 with maxima up to $73 \%, 79 \%$ and $72 \%$ are recorded from the core base until $992 \mathrm{~cm}$ (28.6 to $26.2 \mathrm{cal} \mathrm{kyr} \mathrm{BP),} \mathrm{from} 822$ to $782 \mathrm{~cm}$ (22.4 to $21.2 \mathrm{cal} \mathrm{kyr} \mathrm{BP})$ and at $502 \mathrm{~cm}(8.6$ cal kyr BP).

Tests with models of five or six endmembers yielded a further EM differentiation within the fine grain-size range, but also a higher risk of overfitting and were therefore discarded.

10

15 size variations in the middle and upper part of the core (Fig.3A). Peaks in $\mathrm{Sr} / \mathrm{Rb}$ and $\mathrm{Zr} / \mathrm{Rb}$ ratios are mainly correlated with high EM4 portions.

\subsection{Ordination results of sediment parameters}

The first two PCA axes of the lake-external parameters explain $62.9 \%$ of the variance (Fig.5A). $\mathrm{TiO}_{2}$, EM1 and EM2 plot on values which are also correlated with the $\delta^{13} \mathrm{C}_{\text {Auth Carb }}$ values, the $\mathrm{Sr} / \mathrm{Rb}$ ratio and EM3 in the lower left of the PCA plot. EM4 and EMres plot in the upper left and are strongly anticorrelated with EM2.

The first two PCA axes of the lake-internal parameters explain $81.1 \%$ of the variance of the data. TOC, TOC $_{B r}$ and the TOC/TN ratio plot in the lower right quadrant, while TIC and the Fe/Mn ratio plot in the upper right part of the PCA plot 25 (Fig.5B).

The stratigraphically constrained cluster analysis suggests a division of the core into three zones for the external parameters. External parameter zone 1 (core base to $613 \mathrm{~cm} ; 28.6$ to $13.3 \mathrm{cal} \mathrm{kyr}$ BP) shows negative PCA axis 1 scores up to $1012 \mathrm{~cm}$ depth (26.5 cal kyr BP) and mostly positive values above, while PCA axis 2 scores are almost exclusively positive (Fig.3A). Zone 2 (602 to $452 \mathrm{~cm} ; 13$ to $6.7 \mathrm{cal} \mathrm{kyr} \mathrm{BP})$ plots with a decreasing trend from positive to negative axis 1 scores and 30 variable, mainly positive axis 2 scores. The external parameter zone 3 (442 to $0 \mathrm{~cm} ; 6.6 \mathrm{cal} \mathrm{kyr}$ BP to present day) is characterised by increasing trends for axis 1 and slightly increasing axis 2 sample scores (Fig.3A). 
Clim. Past Discuss., doi:10.5194/cp-2016-34, 2016

Manuscript under review for journal Clim. Past

Published: 7 April 2016

(c) Author(s) 2016. CC-BY 3.0 License.

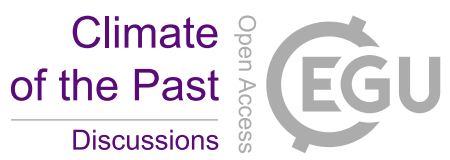

The stratigraphically constrained cluster analysis for the internal parameters results in three zones as well. Samples from internal parameter zone 1 (core base to $713 \mathrm{~cm} ; 28.6$ to $19.2 \mathrm{cal} \mathrm{kyr} \mathrm{BP}$ ) present negative PCA axis 1 and positive and negative PCA axis 2 scores. PCA axis 1 sample scores for the internal parameter zone 2 (712 to $462 \mathrm{~cm}, 17.5$ to 6.9 cal kyr BP) show an increasing trend with mainly negative values, while axis 2 scores are positive throughout zone 2 after rapidly

5 increasing at the beginning of the zone (Fig.3B). The internal parameter zone 3 (452 to $0 \mathrm{~cm} ; 6.7 \mathrm{cal} \mathrm{kyr} \mathrm{BP}$ to present) shows slightly decreasing, still positive, axis 1 scores and both positive and negative, also slightly decreasing axis 2 scores (Fig.3B).

\section{Discussion}

\subsection{Palaeoenvironmental indicators from sedimentary parameters}

10 TOC concentrations reflect preserved organic matter content (Fig.3B), i.e. the balance between allochthonous organic matter input, autochthonous organic matter production, and degradation (Meyers and Lallier-Vergés, 1999), which is affected by runoff, temperature, proximity of the shoreline, ventilation, turbation and other factors (Meyers and Teranes, 2002). We consider $\mathrm{Br}$ as a proxy for organic matter content consistent with previous studies of marine (Mayer et al., 1981; Ziegler et al., 2008) and lake sediments (Kalugin et al., 2007; Biskaborn et al., 2013).

15 The TOC/TN ratios (Fig.3B) probably reflect the source of sedimentary organic matter at the coring position. Values below 10 indicate a dominance of phytoplankton, whereas values of $\geq 18$ indicate a stronger contribution from vascular plant sources (Meyers and Lallier-Vergés, 1999). However, vascular aquatic plants, which can have a wide range of C/N values (Herzschuh et al., 2010), may have dominated, particularly during the last 7 cal kyr BP consistent with the observation of abundant macrophyte remains in the sediments. Hence, the TOC/TN ratios of core KK12-1 most likely indicate a mixed

20 signal from different sources of organic matter. The combined interpretation of organic content and TOC/TN ratios may indicate bioproductivity variations in Lake Karakul.

Total inorganic carbon (TIC) reflect the carbonate content (Fig.3B), most likely originating from allochthonous input of detrital sediments from the catchment and/or as dust, and/or through precipitation from the water column (Cohen, 2003). Visual inspection of smear slides indicated that the carbonate fraction comprises endogenic aragonite crystals, shells and

25 shell fragments of ostracods and gastropods from Lake Karakul. However, it cannot be ruled out that detrital carbonate from the southern part of the catchment is transported to the lake during sporadic floods and that fine-grained carbonate particles of aeolian origin accumulated in the lake basin as well (Strecker et al., 1995).

The good correlation between $\delta^{13} \mathrm{C}$ and $\delta^{18} \mathrm{O}(\mathrm{r}=0.82)$, measured from the authigenic carbonate fraction, reflects the closedbasin setting of Lake Karakul (Talbot, 1990). $\delta^{13} \mathrm{C}$ values (Fig.3A) are influenced by the productivity in the surface waters of

30 the lake, where phytoplankton preferentially incorporate ${ }^{12} \mathrm{C}$, which enriches ${ }^{13} \mathrm{C}$ in the water. $\delta^{13} \mathrm{C}$ values are also controlled by climate conditions. For example, groundwater generation and runoff to the lake is higher during wetter periods, causing 
Clim. Past Discuss., doi:10.5194/cp-2016-34, 2016

Manuscript under review for journal Clim. Past

Published: 7 April 2016

(c) Author(s) 2016. CC-BY 3.0 License.

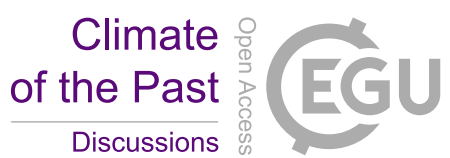

an enhanced transport of soil-derived $\mathrm{CO}_{2}$ with low $\delta^{13} \mathrm{C}$ values to the lake (Talbot, 1990). While $\delta^{18} \mathrm{O}$ values of waters from open lakes generally reflect changes in moisture source, $\delta^{18} \mathrm{O}$ values in closed-lake settings generally reflect changes in the evaporation/precipitation ratio. Higher $\delta^{18} \mathrm{O}$ values represent stronger evaporation and/or less freshwater inflow to the lake. Lower $\delta^{18} \mathrm{O}$ values reflect lower evaporation effects and/or higher runoff entering the lake (Talbot, 1990). Precipitation in the

5 high elevation and very continental location of Lake Karakul is, however, generally low and accordingly, glaciers and snowfields represent the main water source. Therefore, we assume that $\delta^{18} \mathrm{O}$ values mostly display evaporation/freshwater input ratios depicting temperature changes rather than changes in the amount of precipitation. The long-term $\delta^{18} \mathrm{O}$ signal is additionally affected by changes in the $\delta^{18} \mathrm{O}$ signature of the water source (i.e., the ice-volume effect) and the large temperature change over a glacial-interglacial cycle.

10 End-member modelling of grain-size data from the sediment core was applied to decipher different transport and deposition processes of the organic- and carbonate-free sediment fraction (Weltje, 1997). Taking the grain-size distribution in the sediments from core KK12-1 and of modern reference samples into account (Fig.4), the end-member modelling results from Lake Karakul sediments imply that the core sediments represent four different sediment populations (Fig.3A). EM1, with its narrow peak in the fine-grained fraction represents very fine aeolian dust which was probably transported over large 15 distances in high suspension clouds (Wu et al., 2006) and deposited from the atmosphere via precipitation (Vandenberghe et al., 2006; Dietze et al., 2012). Thus EM1 might be indicative of the influence of the Westerlies air stream. EM2 shows a main peak in the fine-moderate silt fraction and probably also reflects remote sources of wind-transported material (Tsoar and Pye, 1987). Loess deposits are not commonly found in the Pamir-Alay region above $3000 \mathrm{~m}$ asl, so EM2 likely represents aeolian sediments transported mostly over long distances (Vandenberghe, 2013). However, the fine-grained

20 sediments of EM1 and EM2 may also include the suspension load of glacial outwash material (glacier milk; Wang et al., 2015). EM3 covers a wide grain-size range similar to the reference samples of fluvial deposits. Hence, its downcore distribution probably represents the fluvial input into the lake and hence summer precipitation events. Accordingly, high portions of EM3 sediments in core KK12-1 are tentatively interpreted as proxies for pronounced summer precipitation, mostly attributed to the Asian Monsoon. However, meltwaters from glacier tongues approaching the lake and local aeolian sediments from alluvial fans and plains may have also contributed to the accumulation of the relatively poorly sorted silts and fine sands of EM3 (Vandenberghe, 2013). EM4 shows similarities with a reference sample of well-sorted aeolian sand. Its coarse grain size indicates a local source area of hundreds of metres to a few kilometres distance and transportation by strong local winds, especially during winter and under snow-free conditions, which enable saltation and creep of grains and transport onto the frozen lake surface (Tsoar and Pye, 1987; Mischke et al., 2010b). The occurrence of EM4 probably

30 reflects strong episodic cyclonal sand and dust storms attributed to an enhanced influence of the Siberian High (Vandenberghe, 2013).

Quantitative single sample XRF measurements over the core enabled the calibration of XRF-scanner data (Weltje and Tjallingii, 2008; Biskaborn et al., 2013). As indicated by the relatively high $\chi^{2}$ values, large uncertainties in the quantitative data occurred which probably originate from inhomogeneities of sediments containing large macrophyte remains and related 
Clim. Past Discuss., doi:10.5194/cp-2016-34, 2016

Manuscript under review for journal Clim. Past

Published: 7 April 2016

(c) Author(s) 2016. CC-BY 3.0 License.

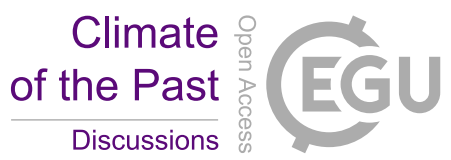

air pockets, low element concentrations, and differing sample preparations (freeze-dried, homogenised milled single samples vs. wet 'in situ' surface core scans (Tjallingii et al., 2007)). Nevertheless, the XRF measurements provide valuable information if the results are regarded as semi-quantitative data (Weltje and Tjallingii, 2008).

Titanium (Ti) and its affiliated oxide (Fig.3A) are often associated with detrital input and clay mineral assemblages,

5 interpreted here as fine clastic input into the lake (Fey et al., 2009; Kylander et al., 2011). This assumption is supported by the opposing trends of $\mathrm{TiO}_{2}$ and the mean grain size of the sediments from Lake Karakul. Sorrel et al. (2007) point out that at Lake Aral in western central Asia, Ti is correlated with the strength of the atmospheric circulation as dust is most likely the dominant source of the detrital-input of Ti in arid and semi-arid regions.

Rubidium $(\mathrm{Rb})$ is commonly found in many K-bearing minerals such as K-feldspar and mica and associated with clay 10 minerals (Kalugin et al., 2007; Liu et al., 2014). As the crossplot of XRF scanner data and XRF single sample measurements show, $\mathrm{Rb}$ exhibits a very low $\mathrm{R}^{2}$. This can be explained by the extremely low concentration of $\mathrm{Rb}$ and the methodological needs to compare the values from prepared single samples with averaged scanner data from the wet and organic-rich sediment core. The main source of Zirconium (Zr) is the heavy mineral Zircon, which is more often released by physical rather than chemical weathering and associated with coarse silt and sand fractions (Chen et al., 2006; Kylander et al., 2011).

15 Strontium ( $\mathrm{Sr}$ ) is usually related to silicates and carbonates because $\mathrm{Ca}$ is often substituted by $\mathrm{Sr}$ in both, feldspar and aragonite (Kalugin et al., 2007; Kylander et al., 2011). The good correlation between the $\mathrm{Sr} / \mathrm{Rb}$ and $\mathrm{Zr} / \mathrm{Rb}$ ratios (Fig.3A) indicates that both ratios apparently serve as grain-size indicators with high ratios tracing larger mean-grain sizes and vice versa. This relationship was also observed in other studies of lake systems (Biskaborn et al., 2013) and other sedimentary environments such as loess deposits on the Tibetan Plateau (Chen et al., 2006). The $\mathrm{Zr} / \mathrm{Rb}$ and $\mathrm{Sr} / \mathrm{Rb}$ ratios of the KK12-1

20 sediments display an opposite trend to $\mathrm{TiO}_{2}$, which is correlated with the finer grain-size fractions.

Fe/Mn ratios (Fig.3B) are generally regarded as a proxy for redox conditions at the bottom of the lake because high values reflect the higher solubility of Mn relative to Fe under reducing conditions (Boyle, 2001). Accordingly, low values indicate a low redox potential (Cohen, 2003). Changes in the redox conditions at the lake floor may have various causes such as changes in lake level, chemical or thermal lake stratification, bioproductivity (e.g. macrophyte growth), or mixing conditions, for example, due to changes in the proximity of a river mouth or the ice-cover duration (Cohen, 2003).

Ordination in the PCA biplots (Fig.5A) displays relationships among the external lake proxies. The first axis separates the wind and dust signal (EM1 and EM2) on the right (positive end) and the precipitation and runoff indicator EM3 on the left (negative) part of the plot. The second axis most likely divides the detrital sediment input into a summer (runoff, EM3) and winter (aeolian sand, EM4) signal, which plot on opposing ends of the axis. The main data structure of the internal lake

30 proxies is shown in Figure 5B. Bioproductivity indicators are plotted along the first PCA axis, whereas the second axis reflects lake-bottom ventilation and possibly lake-level, indicated by the strong correlation with the Fe/Mn ratio and TIC. Carbonate precipitation in a $\mathrm{Mg}^{2+}$ and $\mathrm{SO}_{4}{ }^{2-}$ dominated closed-basin lake normally occurs during periods of sufficient runoff and relatively warm conditions, both facilitating the establishment of a more stratified water column with oxygen deficiency at the lake floor (Mischke et al., 2010b). Thus, axis 2 of $\mathrm{PCA}_{\text {internal }}$ possibly indicates lake level changes. 
Clim. Past Discuss., doi:10.5194/cp-2016-34, 2016

Manuscript under review for journal Clim. Past

Published: 7 April 2016

(c) Author(s) 2016. CC-BY 3.0 License.

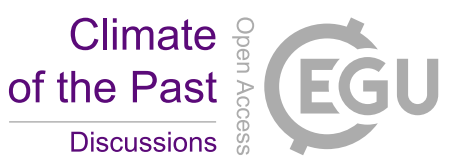

\subsection{Assigning local climate to Asian Monsoon and Westerlies circulation change}

\subsubsection{Pre-LGM to late glacial (28.6 - 13.3 cal kyr BP)}

The pre-LGM phase of the KK12-1 record (zone 1; Fig.3A) is characterized by a high input of EM4 sediments probably indicating strong local cold-season storms. Comparably moderate values of EM1 and low values of EM2 reflect wet deposition of far-transported fine dust but a generally low accumulation of coarser-grained dust. Moderate $\mathrm{Zr} / \mathrm{Rb}$ and $\mathrm{Sr} / \mathrm{Rb}$ ratios possibly result from the presence of feldspars and other minerals susceptible to chemical weathering. High $\delta^{18} \mathrm{O}_{\text {AuthCarb }}$ values could result from significant aridity and strong evaporation from the lake surface which was apparently not sealed off by a long-lasting ice cover.

A dominance of EM2 sediments in the LGM indicates high influx of dust and generally arid and cold conditions. EM4

10 reaches high proportions between 22 and 20 cal kyr BP pointing to dry and stormy winters and low $\mathrm{Zr} / \mathrm{Rb}$ and $\mathrm{Sr} / \mathrm{Rb}$ ratios reflect the dominant role of physical weathering in comparison to chemical processes. Generally decreasing $\delta^{18} \mathrm{O}_{\text {AuthCarb }}$ values during the LGM presumably result from the global cooling, which led to isotopically depleted precipitation in the Karakul region, and decreasing evaporation effects from the lake surface due to prolonged periods of ice-cover.

High values of EM1 during the late glacial point towards a strong Westerlies influence and fine-dust accumulation with

15 precipitation. Increasing EM3 values suggest significant fluvial input into the lake, likely due to increasing temperatures and glacial meltwater discharge. Increasing $\mathrm{Zr} / \mathrm{Rb}$ and $\mathrm{Sr} / \mathrm{Rb}$ ratios mirror the increasing influence of chemical weathering under warmer conditions. Accordingly, high $\delta^{18} \mathrm{O}_{\text {AuthCarb }}$ values probably result from relatively warm temperatures and isotopically less depleted precipitation in the Lake Karakul region.

Strong landslide activity in the north-western Himalaya recorded from 29-24 kyr BP has been interpreted to indicate an

20 intensified Monsoon originating from a steep thermal ocean-land gradient (Bookhagen et al., 2005). Zech et al. (2005) proclaim glacial advances around 27 kyr BP in the southern Pamirs. Dortch et al. (2013), investigating glacial deposits in the western Himalayan range using ${ }^{10} \mathrm{Be}$ surface exposure ages, propose several glacial advancing stages termed semi-arid western Himalayan-Tibetan stages (SWHTS) of which one occurred around 30 $\pm 3 \mathrm{kyr}$ BP (named 2F). These results are in agreement with an increase in moisture availability as pointed out by Bookhagen et al. (2005) but do not necessarily support

25 the stated Monsoon impact during the pre-LGM phase.

Komatsu and Tsukamoto (2015) recorded a late glacial glacier advance in the Karakul catchment at $15 \mathrm{kyr}$ BP and suggested that glaciers responded to enhanced moisture availability from the Westerlies. Their suggestion tallies with the inferences of increased Westerlies precipitation (EM1) and higher fluvial input (EM3) to the lake from the KK12-1 core. Dortch et al. (2013) identified three local glacial stages in the Himalayan-Tibetan mountains between 17 and 14 kyr BP apparently

30 synchronous with the Oldest Dryas and Heinrich event 1 of the Northern Hemisphere and likely controlled by precipitation from the Westerlies. Owen and Dortch (2014) compare the SWHTS with Monsoonal Himalayan-Tibetan stages (MOHITS; Murari et al., 2014) and argue that at times SWHTS and MOHITS were concurrent and probably had similar moisture 
Clim. Past Discuss., doi:10.5194/cp-2016-34, 2016

Manuscript under review for journal Clim. Past

Published: 7 April 2016

(c) Author(s) 2016. CC-BY 3.0 License.

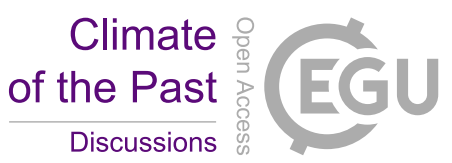

sources while at other times only one of the stages is evident, implying differing climate controls. Various pollen studies from the present monsoonal realm on the eastern Tibetan Plateau report a prevailing cold and dry climate for the LGM period, e.g. from Lake Donggi Cona (Wang et al., 2014), Lake Kuhai (Wischnewski et al., 2011), Lake Naleng (Kramer et al., 2010) and Lake Ximencuo (Herzschuh et al., 2014), which is in agreement with the proxy-record syntheses in Herzschuh

5 (2006) and Wang et al. (2010) that postulate low moisture availability in typical Monsoon areas during Marine Isotope Stage 2. Records of a shut-down of the Asian Summer Monsoon circulation during the LGM also agree with results from various climate modelling studies (Hoffmann and Heimann, 1997; Braconnot et al., 2007). In summary, available proxy information indicate the dominance of the Westerlies in the mountain ranges of Central Asia in the pre-LGM, LGM and late glacial.

\subsubsection{End of the late glacial and early to mid-Holocene (13.3 - 6.7 cal kyr BP)}

10 Indicators of fine aeolian input to the lake (EM1 and 2) have low values between the end of the late glacial and the early Holocene (zone 2; Fig.3A) indicating a diminished Westerlies influence. High values of EM3 imply increased precipitation and surface runoff. A maximum of EM4 and the residual EM at ca. $8.5 \mathrm{cal} \mathrm{kyr}$ BP may indicate the occurrence of especially dry and stormy winters analogous to the LGM or the formation of a single event layer of aeolian sand. Maximum $\mathrm{Sr} / \mathrm{Rb}$ and $\mathrm{Zr} / \mathrm{Rb}$ ratios probably reflect increased grain-size due to intensified chemical weathering and physical weathering. Lowest

$15 \mathrm{TiO}_{2}$ values result from decreased far-distant detrital input of fine aeolian sediments. The $\delta^{18} \mathrm{O}_{\text {AuthCarb }}$ values are high at the end of the late glacial and during the early and mid- Holocene, most likely reflecting the rising global temperatures and arrival of less depleted precipitation in Lake Karakul's catchment. The high $\delta^{18} \mathrm{O}_{\text {AuthCarb }}$ values could be further amplified by increased evaporation due to increased temperatures and shorter ice-cover periods. A significant change in the prevailing climate system and a shift from a Westerlies-driven to a more Monsoon-influenced climate is inferred at the start of the

20 Allerød period.

Global temperature rose strongly during the Bølling/Allerød and early Holocene until approximatly 9.5 kyr BP and stayed high until about 5.5 kyr BP (Marcott et al., 2013). At Lake Donggi Cona wetter conditions were reconstructed during the early and mid-Holocene (Wang et al., 2014), as well as at Lake Sumxi Co, where early-Holocene high-stands are derived from ${ }^{10} \mathrm{Be}$-dated shorelines (Kong et al., 2007). This also agrees with several pollen-derived palaeoclimate studies from

25 Central Asia (Lake Sumxi Co, Van Campo and Gasse, 1993; Lake Bangong Co, Gasse et al., 1996; Van Campo et al., 1996 ; Lake Kuhai, Wischnewski et al., 2011). Zhu et al. (2015) investigated modern pollen spectra at Lake Nam Co, assigning certain taxa to dominant wind directions/circulatory systems and developing a pollen discrimination index which was used to reconstruct the predominant circulations over time. Their study suggests that an enhanced Asian Monsoon, driven by increased solar radiation, was responsible for increased moisture availability on the Tibetan Plateau in the early Holocene.

30 Seong et al. (2009) infer several glacial advances in the Muztag Ata and Kongur Shan during the early Holocene and argue towards a moisture transport from the middle latitude Westerlies. Other studies from Westerlies-impacted regions such as the Eastern Mediterranean and the Levant likewise indicate a wet early Holocene, after a dry phase during the Younger Dryas 
Clim. Past Discuss., doi:10.5194/cp-2016-34, 2016

Manuscript under review for journal Clim. Past

Published: 7 April 2016

(c) Author(s) 2016. CC-BY 3.0 License.

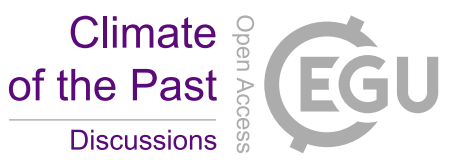

(Robinson et al., 2006). However, Herzschuh (2006) relates the wet conditions on the Tibetan Plateau during the early Holocene to a strengthened Asian Monsoon influence on the Tibetan Plateau that decreased towards the mid-Holocene. Chen et al. (2008), on the other hand, propose an out-of-phase relationship between arid Central Asia and the Monsoon-influenced regions of Asia and point out that a dry early and moist mid-Holocene prevailed in the former and maximum moisture

5 availability during the early and mid-Holocene in the latter. However, their review does not include any study from the Pamir, western Himalaya or northern Tibetan Plateau. Zhao et al. (2009) also compare moisture availability and proclaim asynchrony as expected, yet draw a more differentiated picture and reconstruct the wettest conditions on the northern Tibetan Plateau at the onset of the Holocene, which is in accordance with our findings from the Pamir Mountains.

\subsubsection{7 cal kyr BP until present}

10 From $6.7 \mathrm{cal}$ kyr BP onward (zone 3; Fig.3A) EM1 and EM2 show an increasing trend, reflecting an enhanced influence of the Westerlies. EM4 shows a more sporadic pattern towards the present day which likely reflects reduced winter storms and the weakening influence of the Siberian High. EM3 displays slightly declining values accelerated in the last 2 cal kyr BP, which implies decreasing monsoonal precipitation. Decreasing $\mathrm{Sr} / \mathrm{Rb}$ and $\mathrm{Zr} / \mathrm{Rb}$ ratios correspond to a decreasing mean grain size and a steady increase in $\mathrm{TiO}_{2}$ emphasizing the increasing far-distance dust input and diminishing influence of chemical

15 weathering. Declining $\delta^{18} \mathrm{O}_{\text {AuthCarb }}$ values are probably recording the global cooling trend since the mid-Holocene with a strong depletion of incoming moisture. However, decreasing $\delta^{18} \mathrm{O}_{\text {AuthCarb }}$ values may also indicate a reduction in commonly less depleted monsoonal precipitation in comparison to more depleted precipitation from the west and/or a declining evaporation and longer ice cover of the lake.

Liu et al. (2014), in their study of glacial activities in the westernmost Tibetan Plateau based on multi-proxy analyses of

20 glaciolacustrine sediments from Lake Karakuli ( 150 km south-east of Lake Karakul), find a general correlation of local glacier advances with Holocene ice-rafting events in the northern Atlantic. However, glacier retreats reflect the general global warming and were not compensated by short phases of higher moisture availability. Ricketts et al. (2001) infer for Lake Issyk-Kul, located $\sim 480 \mathrm{~km}$ north-east of Lake Karakul, a wet period preceding 6.9 cal kyr BP, suggesting an increased moisture transport from the west or a possible Asian Monsoon influence. Lake Issyk-Kul experienced an increasing influence of the Siberian High, causing drier air masses and decreasing moisture availability in the region between 6.9 and $4.9 \mathrm{cal}$ kyr BP. Subsequently the lake changed from an open freshwater system to a closed basin after a regression of the lake level, which corresponds with the findings at Lake Karakul for the mid- to late Holocene.

Many case studies including speleothem records, lake sediments, dating of paleo-shorelines and reviews of such studies, suggest a decreasing Asian Monsoon during the mid- to late Holocene related to the decreasing Northern Hemisphere 30 summer insolation (Kutzbach, 1981; Hulu Cave, Wang et al., 2001; Dongge Cave; Dykoski et al., 2005; caves in Oman and Yemen, Fleitmann et al., 2007; Lake Qinghai, Ji et al., 2005; An et al., 2012; Lake Sumxi Co, Van Campo and Gasse, 1993; Lake Bangong Co, Gasse et al., 1996; Van Campo et al., 1996; Lake Tangra Yum Co, Rades et al., 2015; reviews, 
Clim. Past Discuss., doi:10.5194/cp-2016-34, 2016

Manuscript under review for journal Clim. Past

Published: 7 April 2016

(c) Author(s) 2016. CC-BY 3.0 License.

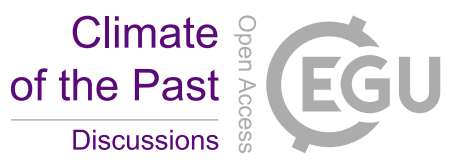

Herzschuh, 2006; Chen et al., 2008). More Westerlies-influenced study sites such as Lake Van experienced a climatic optimum between 6 and $4 \mathrm{kyr}$ BP reflected in a higher lake level and in the spread of oak trees, implying increased moisture availability during the growthing season. After 4 kyr BP, a more continental climate influenced the region, resulting in drier conditions (Wick et al., 2003).

\section{$5 \quad 5.3$ Assigning lake internal development to climate change}

\subsubsection{Pre-LGM and LGM (28.6 - $19.2 \mathrm{cal} \mathrm{kyr}$ BP)}

Low PCA $\mathrm{P}_{\text {internal }}$ axis 1 sample scores and low TOC suggest low bioproductivity and poor preservation of organic matter. Bioproductivity reaches minimum during the LGM. TOC/TN values are only measurable in four samples during the preLGM due to very low TN values, confirming the low productivity during the pre-LGM and LGM (zone 1; Fig.3B). Moderate

10 TIC and $\mathrm{PCA}_{\text {internal }}$ axis 2 values during the pre-LGM show that inflow to the lake and resulting carbonate precipitation was still significant before the onset of the LGM. TIC and $\mathrm{PCA}_{\text {internal }}$ axis 2 values decreased rapidly towards the LGM where minimum values were reached. Thus low inflow, reduced carbonate precipitation and a low lake level existed during the LGM. Low Fe/Mn ratios, as a redox proxy, imply a well-mixed waterbody with sufficient dissolved oxygen at the lake bottom. This inference corresponds with the reconstructed cold and windy climate. Accordingly, climate is surmised to be

15 the main driver of the lake's internal conditions during the pre-LGM and LGM.

Low primary production and low lake levels are also reconstructed by Wünnemann et al. (2012) for Lake Hala in the Qilian Mountains on the northern Tibetan Plateau, which is located in a comparable alpine setting. Very low TOC values have also been recorded from many other lakes on the Tibetan Plateau, suggesting low bioproductivity and cold temperatures during the LGM (An et al., 2012; Zhang and Mischke, 2009; Zhu et al., 2015). Although only few dates are available at Lake Issyk-

$20 \mathrm{Kul}$ in Kyrgyzstan, situated north-east of lake Karakul, lacustrine terrace sediments $33 \mathrm{~m}$ above current lake level indicate a period of lake-level high-stands starting around $26 \mathrm{kyr}$ BP and lasting until the late glacial (non-accessible literature in Russian quoted in Romanovsky (2002) and Ricketts et al. (2001)). However, better chronological evidence from the exposed shorelines of Lake Issyk-Kul is required for a detailed assessment of its history in the late Pleistocene. Similar dates for highstands were recorded for Lake Van in eastern Turkey, west of our study region, at approximately $26 \mathrm{kyr}$ BP and the end of the LGM (Kuzucuoğlu et al., 2010; Reimer et al., 2008). At Lake Karakul moderate to low lake levels were reconstructed during this period. Thus although the system is climate driven, it does not show the same lake evolution as the other two Westerlies-influenced lakes and reacts, at least in part independently, which might be due to a relocation of the Westerlies during the LGM or to the buffering capability of Lake Karakul. 
Clim. Past Discuss., doi:10.5194/cp-2016-34, 2016

Manuscript under review for journal Clim. Past

Published: 7 April 2016

(c) Author(s) 2016. CC-BY 3.0 License.

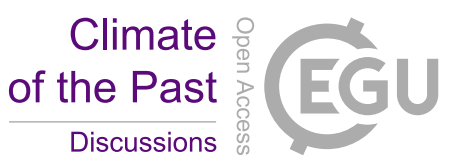

\subsubsection{Late glacial and early to mid-Holocene (17.5 until approx. 6.9 kyr BP)}

The late glacial is characterized by continuously low and slightly increasing TOC values indicating that the production of organic matter and its preservation increased slightly but remained comparably low. TOC/TN data reveal values below 10 and signal a prevailing bioproductivity by algae. The slight increase in bioproductivity is indicated from the continuously

5 increasing $\mathrm{PCA}_{\text {internal }}$ axis 1 values. TIC values rise rapidly and reach maximum values during the late glacial, indicating high runoff and enhanced carbonate precipitation. The Fe/Mn ratios show a significant increase during the late glacial and culminate during the onset of the Holocene. The increase in bioproductivity and runoff was apparently accompanied by a decreasing availability of dissolved oxygen at the lake floor. The $\mathrm{PCA}_{\text {internal }}$ axis 2 scores are high during the late glacial and early to mid- Holocene, probably reflecting a high lake level (zone 2; Fig.3B). This inference is supported by the study of

10 Komatsu and Tsukamoto (2015) who propose a maximum lake level of $35 \mathrm{~m}$ for Lake Karakul during the late glacial. They argue that cold and wet conditions with moisture of Westerlies' origin caused glacier advances down to the lake at $15 \mathrm{kyr}$ BP. Further evidence for relatively wet conditions during the late glacial and advancing glaciers is provided by Dortch et al. (2013) who infer several glacier advances (SWTHS 2D-2A) during the late glacial. Seong et al. (2009) investigated moraines in the Muztag Ata and Kongur Shan massifs $170 \mathrm{~km}$ to the south-east of Lake Karakul, and suggest glacial advances around

1517 and $13.7 \mathrm{kyr}$ BP. Regional differences in the timing of glacier advances are probably related to the specific topographic settings of glaciers and related response times, and to age uncertainties.

Similar to the KK12-1 record other lakes such as the Monsoon influenced Lake Donggi Cona experienced an increase in lake level between 17.8 and 13.8 cal kyr BP (Opitz et al., 2012) due to increased meltwater input triggered by late-glacial warming. In contrast, lakes farther west of Lake Karakul such as Lake Van in Anatolia or the Dead Sea in the Levant

20 experienced a rapid drop in lake level after 21 kyr BP (Landmann et al., 1996a, 1996b; Çağatay et al., 2014; Stein, 2014). This lake level regression lasted until the early Holocene at Lake Van (Landmann et al., 1996; Çağatay et al., 2014) or until 14 cal kyr BP in the Dead Sea (Stein, 2014). The contrary scenarios for Lake Karakul and Lake Van and the Dead Sea in the west during the late glacial possibly result from a latitudinal re-arrangement of the Westerlies after the disappearance of the Scandinavian ice sheet, and from the late glacial water sources in the Karakul catchment stored as snow and ice.

25 Early Holocene TOC values remained relatively low in contrast to rapidly increasing Fe/Mn ratio (zone 2; Fig.3B). The high TIC values indicate that runoff to the lake was high. In consequence, a relatively unchanged bioproductivity and rapidly increasing lake level is inferred for the early Holocene, which led to the establishment of poorly oxygenated bottom waters in Lake Karakul. The inferred moderate bioproductivity in the lake possibly results from relatively low lake-water temperatures in comparison to air temperatures due to the enhanced input of glacial meltwater. Climate is suggested as the

30 main driver of the internal lake development, with the Monsoon considered as the main influence in agreement with studies identifying a stronger Monsoon during the early and mid-Holocene as result of high summer insolation in temperate latitudes (Kutzbach, 1981). This inference is in accordance with Ricketts et al. (2001), who examined trace elements and $\square^{18} \mathrm{O}$ values of ostracod shells, and reconstructed a high freshwater input into Lake Issyk-Kul either due to increased moisture of 
Clim. Past Discuss., doi:10.5194/cp-2016-34, 2016

Manuscript under review for journal Clim. Past

Published: 7 April 2016

(c) Author(s) 2016. CC-BY 3.0 License.

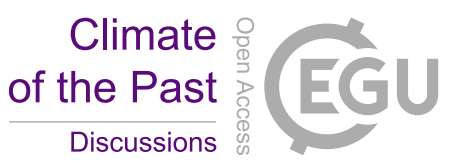

Westerlies' origin or due to a monsoonal influence from the beginning of their record at 8.7 to $8.3 \mathrm{cal} \mathrm{kyr}$ BP. A relatively stable high lake level with sufficient inflow prevailed at Lake Issyk-Kul until 6.9 cal kyr BP, coinciding with our findings for the early and mid-Holocene. On the other hand, Lake Ulungur experienced low lake levels between 10 and 6 cal kyr BP with a minimum around $7.6 \mathrm{cal}$ kyr BP (Mischke and Zhang, 2010), while Boston Lake did not exist before approx. 8 kyr BP

5 (Wünnemann et al., 2006; Huang et al., 2009). It remains speculative whether Lake Karakul was influenced by the northward penetration of the Indian Monsoon during the early and mid-Holocene whilst the lakes in north-west China remained unaffected by monsoonal precipitation.

\subsubsection{6 cal kyr BP until present}

High TOC values and $\mathrm{PCA}_{\text {internal }}$ axis 1 scores signal high bioproductivity during the last 6.6 cal kyr BP (zone 3; Fig.3A).

10 Values for TOC/TN between 10 and 16 reflect a shift in organic matter origin from purely planktonic to more mixed sources: planktonic, macrophytes, macroalgae, and/or terrestrial. This shift is most likely explained by the occurrence of Potamogeton, a C3 submerged macrophyte (Edwards and Walker, 1983), as abundant remains of recorded in the upper part of the core, rather than the increased input of terrestrial plants. Continuously decreasing $\mathrm{Fe} / \mathrm{Mn}$ ratios point towards increasing ventilation, probably due to a decreasing lake level and better oxygenation of bottom waters. The inferred lower lake level after $6.6 \mathrm{cal}$ kyr BP likely resulted from a weaker Monsoon, which retreated from the study area, and from reduced meltwater inflow from glaciers in the catchment. The lowered lake level probably favoured the expansion of macrophytes at the lake bottom due to sufficient mixing and light penetration. At approximately $6.6 \mathrm{kyr} \mathrm{BP}$, a threshold seems to have been crossed, enabling an increased growth of the lake bottom at the core position. The decreasing TIC values probably reflect a decreasing inflow. The lake interior development is assumed to be mainly related to the aridification of climate during the last $6.6 \mathrm{cal} \mathrm{kyr} \mathrm{BP}$.

A similar development to Lake Karakul is inferred at Lake Issyk-Kul where the $\square^{18} \mathrm{O}$ values of ostracod shells suggest a major change in hydrology in the lake between 6.9 and $4.9 \mathrm{kyr}$ BP (Ricketts et al., 2001). Ricketts et al. (2001) surmise a shift from an open lake system to a mostly closed lake system related to increasing aridity and changes in atmospheric circulation patterns with a dominance of drier air masses compared to the mid-Holocene. The study by Ricketts et al. (2001) suggests increased biological productivity at Lake Issyk-Kul during the second half of the Holocene, after the shift to a closed system, corresponding to our findings from Lake Karakul for the last 6.7 cal kyr BP. A trend towards cooler conditions from about 3.5 to 1.9 cal kyr BP is reported for Lake Karakul by Mischke et al. (2010) and Taft et al. (2014), who investigated the last $4.2 \mathrm{kyr}$ BP at high resolution. Low TOC values and low Fe/Mn ratios in core KK12-1 support these assumptions, implying decreased bioproductivity and increased mixing and ventilation of the lake floor. From approximately

301.9 cal kyr BP onwards a warmer phase led to increased meltwater supply (Mischke et al., 2010b; Taft et al., 2014) reflected by increased Fe/Mn values in core KK12-1 until 0.6 kyr BP and drier conditions afterwards in accordance with Mischke et al. (2010b). 
Clim. Past Discuss., doi:10.5194/cp-2016-34, 2016

Manuscript under review for journal Clim. Past

Published: 7 April 2016

(c) Author(s) 2016. CC-BY 3.0 License.

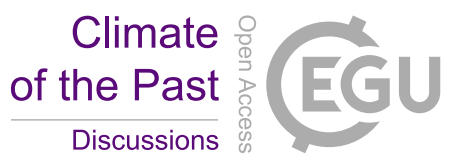

(c) (i)

\section{Conclusions}

The results of record KK12-1 from Lake Karakul, covering the last 28.6 cal kyr BP, contribute to our understanding of the interactions between the atmosphere and high-mountain environments and to the current discussion about atmospheric circulation in arid central Asia. First, we assessed the palaeoenvironmenal indicator value of each sedimentary parameter.

5 We assigned $\delta^{18} \mathrm{O}_{\text {AuthCarb }}, \delta^{13} \mathrm{C}_{\text {AuthCarb}}, \mathrm{TiO}_{2}, \mathrm{Sr} / \mathrm{Rb}, \mathrm{Zr} / \mathrm{Rb}, \mathrm{EM} 1-4$ to indicate lake-external climate and TOC, TOC ${ }_{B r}$, TIC, $\mathrm{TOC} / \mathrm{TN}$ and $\mathrm{Fe} / \mathrm{Mn}$ to reveal lake internal variations, identifying suitable proxies to investigate changes in lake-external and lake-internal conditions.

Based on the assessed proxies we identified three climatic phases:

1) The Karakul region was predominantly influenced by the Westerlies during the pre-LGM, LGM and late glacial.

2) Towards the end of the glacial and in the early and first half of the mid-Holocene (until approx. 6.7 cal kyr BP) the Monsoon appeared to increase in strength in response to increased summer insolation, allowing the transport of moist air masses farther north into the Pamir Mountains during summer.

3) The monsoonal influence started to decrease during the second half of the mid-Holocene and the Westerlies regained their dominant role again, causing arid conditions in the Pamir Mountains during the late Holocene.

15

Reconstructed lake-internal changes were mainly related to changes in the productivity and redox condition at the lake bottom. A low lake level, coinciding with high ventilation and low productivity prevailed during the pre-LGM and LGM at Lake Karakul, followed by a lake level high-stand during the late glacial and early to mid-Holocene (17.5 until $~ 6.7$ cal kyr BP). Productivity increased rapidly with enhanced ventilation and reducing lake levels from 6.7 cal kyr BP onwards. Comparisons of lake-internal signals from Lake Karakul with those from other relatively deep lakes in the Westerlies region suggest that the sedimentary regime in Lake Karakul was largely driven by climate, which is not unexpected, as it is mainly fed by glacial meltwater.

Lake Karakul has proven to be a suitable archive of paleoenvironmental data and our study contributes to the understanding of the region, adding to the few paleolimnological studies that have been conducted in Central Asia so far.

\section{Acknowledgements}

We thank Romy Zibulski for identification and discussions of the moss remains, Zafar Mahmoudov and Tim Jonas for help during fieldwork, and Matthias Röhl for support with core description. We appreciate the financial support of the DFG (grants Mi 730/15-1 and 15-2; and PhD scholarship for LH in the DFG Graduate School 1364). 
Clim. Past Discuss., doi:10.5194/cp-2016-34, 2016

Manuscript under review for journal Clim. Past

Published: 7 April 2016

(c) Author(s) 2016. CC-BY 3.0 License.

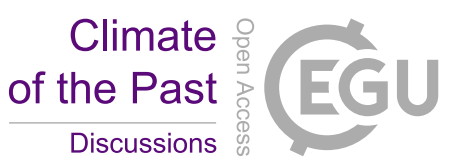

\section{References}

Abramowski, U., Bergau, A., Seebach, D., Zech, R., Glaser, B., Sosin, P., Kubik, P. W. and Zech, W.: Pleistocene glaciations of Central Asia: results from 10Be surface exposure ages of erratic boulders from the Pamir (Tajikistan), and the Alay-Turkestan range (Kyrgyzstan), Quat. Sci. Rev., 25(9-10), 1080-1096, doi:10.1016/j.quascirev.2005.10.003, 2006.

5 Aizen, E. M., Aizen, V. B., Melack, J. M., Nakamura, T. and Ohta, T.: Precipitation and atmospheric circulation patterns at mid-latitudes of Asia, Int. J. Climatol., 21(5), 535-556, doi:10.1002/joc.626, 2001.

An, Z., Colman, S. M., Zhou, W., Li, X., Brown, E. T., Jull, A. J. T., Cai, Y., Huang, Y., Lu, X., Chang, H., Song, Y., Sun, Y., Xu, H., Liu, W., Jin, Z., Liu, X., Cheng, P., Liu, Y., Ai, L., Li, X., Liu, X., Yan, L., Shi, Z., Wang, X., Wu, F., Qiang, X., Dong, J., Lu, F. and Xu, X.: Interplay between the Westerlies and Asian monsoon recorded in Lake Qinghai sediments since

1032 ka, Sci. Rep., 2, doi:10.1038/srep00619, 2012.

Birks, H. J. B. and Birks, H. H.: Quaternary palaeoecology, Edward Arnold London. [online] Available from: http://tocs.ulb.tu-darmstadt.de/24485187.pdf (Accessed 2 January 2016), 1980.

Biskaborn, B. K., Herzschuh, U., Bolshiyanov, D. Y., Schwamborn, G. and Diekmann, B.: Thermokarst Processes and Depositional Events in a Tundra Lake, Northeastern Siberia, Permafr. Periglac. Process., 24(3), n/a-n/a, doi:10.1002/ppp.1769, 2013.

Blaauw, M. and Christen, J. A.: Flexible paleoclimate age-depth models using an autoregressive gamma process, Bayesian Anal., 6(3), 457-474, doi:10.1214/ba/1339616472, 2011.

Böhner, J.: General climatic controls and topoclimatic variations in Central and High Asia, Boreas, 35(2), 279-295, doi:10.1111/j.1502-3885.2006.tb01158.x, 2006.

20 Bookhagen, B., Thiede, R. C. and Strecker, M. R.: Late Quaternary intensified monsoon phases control landscape evolution in the northwest Himalaya, Geology, 33(2), 149-152, doi:10.1130/G20982.1, 2005.

Boyle, J. F.: Inorganic Geochemical Methods in Palaeolimnology, in Tracking Environmental Change Using Lake Sediments, vol. Physical and Geochemical Methods, edited by W. M. Last and J. P. Smol, pp. 83-141, Kluwer Academic Publishers, Dordrecht. [online] Available from: http://link.springer.com/chapter/10.1007/0-306-47670-3_5 (Accessed 4

25 January 2016), 2001.

Braak, C. J. F. ter and Šmilauer, P.: Canoco reference manual and user's guide: software for ordination, version 5.0, Microcomputer Power, Ithaca USA. [online] Available from: http://library.wur.nl/WebQuery/wurpubs/personal/431861 (Accessed 16 February 2016), 2012.

Braconnot, P., Otto-Bliesner, B., Kageyama, M., Kitoh, A., Laîné, A., Loutre, M.-F., Marti, O., Merkel, U., Ramstein, G., 30 Valdes, P. and others: Results of PMIP2 coupled simulations of the Mid-Holocene and Last Glacial Maximum-Part 1: experiments and large-scale features, Clim. Past, 3, 261-277 doi:10.5194/cp-3-261-2007, 2007.

Çağatay, M. N., Öğretmen, N., Damc1, E., Stockhecke, M., Sancar, Ü., Eriş, K. K. and Özeren, S.: Lake level and climate records of the last 90 ka from the Northern Basin of Lake Van, eastern Turkey, Quat. Sci. Rev., 104, 97-116, doi:10.1016/j.quascirev.2014.09.027, 2014.

35 Chen, F., Yu, Z., Yang, M., Ito, E., Wang, S., Madsen, D. B., Huang, X., Zhao, Y., Sato, T., John B. Birks, H., Boomer, I., Chen, J., An, C. and Wünnemann, B.: Holocene moisture evolution in arid central Asia and its out-of-phase relationship with Asian monsoon history, Quat. Sci. Rev., 27(3-4), 351-364, doi:10.1016/j.quascirev.2007.10.017, 2008. 
Clim. Past Discuss., doi:10.5194/cp-2016-34, 2016

Manuscript under review for journal Clim. Past

Published: 7 April 2016

(c) Author(s) 2016. CC-BY 3.0 License.

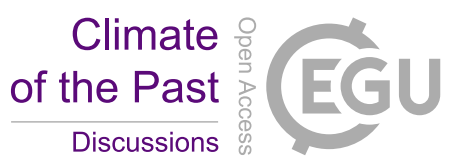

Chen, F.-H., Chen, J.-H., Holmes, J., Boomer, I., Austin, P., Gates, J. B., Wang, N.-L., Brooks, S. J. and Zhang, J.-W.: Moisture changes over the last millennium in arid central Asia: a review, synthesis and comparison with monsoon region, Quat. Sci. Rev., 29(7-8), 1055-1068, doi:10.1016/j.quascirev.2010.01.005, 2010.

Cheng, H., Zhang, P. Z., Spötl, C., Edwards, R. L., Cai, Y. J., Zhang, D. Z., Sang, W. C., Tan, M. and An, Z. S.: The 5 climatic cyclicity in semiarid-arid central Asia over the past 500,000 years, Geophys. Res. Lett., 39(1), L01705, doi:10.1029/2011GL050202, 2012.

Chen, J., Chen, Y., Liu, L., Ji, J., Balsam, W., Sun, Y. and Lu, H.: Zr/Rb ratio in the Chinese loess sequences and its implication for changes in the East Asian winter monsoon strength, Geochim. Cosmochim. Acta, 70(6), 1471-1482, doi:10.1016/j.gca.2005.11.029, 2006.

10 Cohen, A. S.: Paleolimnology: the history and evolution of lake systems, Oxford University Press, USA., 2003.

Dietze, E., Hartmann, K., Diekmann, B., IJmker, J., Lehmkuhl, F., Opitz, S., Stauch, G., Wünnemann, B. and Borchers, A.: An end-member algorithm for deciphering modern detrital processes from lake sediments of Lake Donggi Cona, NE Tibetan Plateau, China, Sediment. Geol., 243-244, 169-180, doi:10.1016/j.sedgeo.2011.09.014, 2012.

Dietze, M. and Dietze, E.: EMMAgeo: End-member modelling algorithm and supporting functions for grain-size analysis, R package version 0.9. 0. [online] Available from: https://cran.r-project.org/web/packages/EMMAgeo/index.html, 2013.

Dortch, J. M., Owen, L. A. and Caffee, M. W.: Timing and climatic drivers for glaciation across semi-arid western Himalayan-Tibetan orogen, Quat. Sci. Rev., 78, 188-208, doi:10.1016/j.quascirev.2013.07.025, 2013.

Dykoski, C. A., Edwards, R. L., Cheng, H., Yuan, D., Cai, Y., Zhang, M., Lin, Y., Qing, J., An, Z. and Revenaugh, J.: A high-resolution, absolute-dated Holocene and deglacial Asian monsoon record from Dongge Cave, China, Earth Planet. Sci. Lett., 233(1-2), 71-86, doi:10.1016/j.eps1.2005.01.036, 2005.

Edwards, G. and Walker, D.: C3, C4: Mechanisms, and Cellular and Environmental Regulation of Photosynthesis, University of California Press., 1983.

Ergashev, A. E.: The origin and typology of the Central Asian lakes and their algal flora, Int. Rev. Gesamten Hydrobiol., 64, 629-642, 1979.

25 Fey, M., Korr, C., Maidana, N. I., Carrevedo, M. L., Corbella, H., Dietrich, S., Haberzettl, T., Kuhn, G., Lücke, A., Mayr, C., Ohlendorf, C., Paez, M. M., Quintana, F. A., Schäbitz, F. and Zolitschka, B.: Palaeoenvironmental changes during the last 1600 years inferred from the sediment record of a cirque lake in southern Patagonia (Laguna Las Vizcachas, Argentina), Long-Term Multi-Proxy Clim. Reconstr. Dyn. S. Am. LOTRED-SA State Art Perspect., 281(3-4), 363-375, doi:10.1016/j.palaeo.2009.01.012, 2009.

30 Fleitmann, D., Burns, S. J., Mangini, A., Mudelsee, M., Kramers, J., Villa, I., Neff, U., Al-Subbary, A. A., Buettner, A., Hippler, D. and Matter, A.: Holocene ITCZ and Indian monsoon dynamics recorded in stalagmites from Oman and Yemen (Socotra), Quat. Sci. Rev., 26(1-2), 170-188, doi:10.1016/j.quascirev.2006.04.012, 2007.

Fuchs, M. C., Gloaguen, R., Krbetschek, M. and Szulc, A.: Rates of river incision across the main tectonic units of the Pamir identified using optically stimulated luminescence dating of fluvial terraces, Geomorphology, 216, 79-92,

doi:10.1016/j.geomorph.2014.03.027, 2014. 
Clim. Past Discuss., doi:10.5194/cp-2016-34, 2016

Manuscript under review for journal Clim. Past

Published: 7 April 2016

(c) Author(s) 2016. CC-BY 3.0 License.

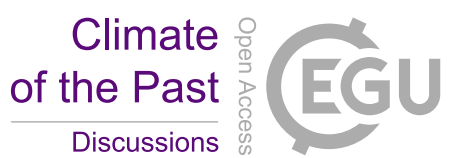

Fuchs, M. C., Gloaguen, R., Merchel, S., Pohl, E., Sulaymonova, V. A., Andermann, C. and Rugel, G.: Millennial erosion rates across the Pamir based on $10 \mathrm{Be}$ concentrations in fluvial sediments: dominance of topographic over climatic factors, Earth Surf. Dyn. Discuss., 3(1), 83-128, 2015.

Gasse, F., Fontes, J. C., Van Campo, E. and Wei, K.: Holocene environmental changes in Bangong Co basin (Western 5 Tibet). Part 4: Discussion and conclusions, Palaeogeogr. Palaeoclimatol. Palaeoecol., 120(1-2), 79-92, doi:10.1016/00310182(95)00035-6, 1996.

Gebhardt, A. C., Naudts, L., De Mol, L., Klerkx, J., Abdrakhmatov, K., Sobel, E. R. and De Batist, M.: An extended history of high-amplitude lake-level changes in tectonically active Lake Issyk-Kul (Kyrgyzstan), as revealed by high-resolution seismic reflection data, Clim. Past Discuss., 1-36, doi:10.5194/cp-2016-3, 2016.

10 Grimm, E. C.: CONISS: a FORTRAN 77 program for stratigraphically constrained cluster analysis by the method of incremental sum of squares, Comput. Geosci., 13(1), 13-35, 1987.

Hammer, U. T.: Saline Lake Ecosystems of the World, Springer Science \& Business Media., 1986.

Herzschuh, U.: Palaeo-moisture evolution in monsoonal Central Asia during the last 50,000 years, Quat. Sci. Rev., 25(1-2), 163-178, doi:10.1016/j.quascirev.2005.02.006, 2006.

15 Herzschuh, U., Borkowski, J., Schewe, J., Mischke, S. and Tian, F.: Moisture-advection feedback supports strong early-tomid Holocene monsoon climate on the eastern Tibetan Plateau as inferred from a pollen-based reconstruction, Palaeogeogr. Palaeoclimatol. Palaeoecol., 402, 44-54, doi:10.1016/j.palaeo.2014.02.022, 2014.

Hoffmann, G. and Heimann, M.: Water isotope modelling in the Asian monsoon region, Quat. Int., 37, 115-128, doi:10.1016/1040-6182(96)00004-3, 1997.

20 Holmes, J. A., Cook, E. R. and Yang, B.: Climate change over the past 2000 years in Western China, Quat. Int., 194(1-2), 91-107, doi:10.1016/j.quaint.2007.10.013, 2009.

Huang, X. Z., Chen, F. H., Fan, Y. X. and Yang, M. L.: Dry late-glacial and early Holocene climate in arid central Asia indicated by lithological and palynological evidence from Bosten Lake, China, Quat. Int., 194(1-2), 19-27, doi:10.1016/j.quaint.2007.10.002, 2009.

25 Hudson, A. M. and Quade, J.: Long-term east-west asymmetry in monsoon rainfall on the Tibetan Plateau, Geology, 41(3), 351-354, doi:10.1130/G33837.1, 2013.

Ji, S., Xingqi, L., Sumin, W. and Matsumoto, R.: Palaeoclimatic changes in the Qinghai Lake area during the last 18,000 years, Quat. Int., 136(1), 131-140, doi:10.1016/j.quaint.2004.11.014, 2005.

Kalugin, I., Daryin, A., Smolyaninova, L., Andreev, A., Diekmann, B. and Khlystov, O.: 800-yr-long records of annual air

30 temperature and precipitation over southern Siberia inferred from Teletskoye Lake sediments, Quat. Res., 67(3), 400-410, doi:10.1016/j.yqres.2007.01.007, 2007.

Komatsu, T.: Field photographs of geomorphic features in the lake Karakul region, eastern Pamirs, Geogr Stud, 84, 44-50, 2009.

Komatsu, T. and Tsukamoto, S.: Late Glacial lake-level changes in the Lake Karakul basin (a closed glacierized-basin), eastern Pamirs, Tajikistan, Quat. Res., 83(1), 137-149, doi:10.1016/j.yqres.2014.09.001, 2015. 
Clim. Past Discuss., doi:10.5194/cp-2016-34, 2016

Manuscript under review for journal Clim. Past

Published: 7 April 2016

(c) Author(s) 2016. CC-BY 3.0 License.

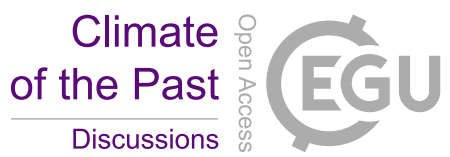

Komatsu, T., Watanabe, T. and Hirakawa, K.: A framework for Late Quaternary lake-level fluctuations in Lake Karakul, eastern Pamir, focusing on lake-glacier landform interaction, Geomorphology, 119(3-4), 198-211, doi:10.1016/j.geomorph.2010.03.025, 2010.

Kong, P., Na, C., Fink, D., Huang, F. and Ding, L.: Cosmogenic 10 Be inferred lake-level changes in Sumxi Co basin, 5 Western Tibet, J. Asian Earth Sci., 29(5), 698-703, 2007.

Kramer, A., Herzschuh, U., Mischke, S. and Zhang, C.: Late glacial vegetation and climate oscillations on the southeastern Tibetan Plateau inferred from the Lake Naleng pollen profile, Quat. Res., 73(2), 324-335, doi:10.1016/j.yqres.2009.12.003, 2010 .

Kutzbach, J. E.: Monsoon climate of the early Holocene: climate experiment with the earth's orbital parameters for 9000 10 years ago, Science, 214(4516), 59-61, 1981.

Kuzucuoğlu, C., Christol, A., Mouralis, D., Doğu, A.-F., Akköprü, E., Fort, M., Brunstein, D., Zorer, H., Fontugne, M., Karabiyikoğlu, M., Scaillet, S., Reyss, J.-L. and Guillou, H.: Formation of the Upper Pleistocene terraces of Lake Van (Turkey), J. Quat. Sci., 25(7), 1124-1137, doi:10.1002/jqs.1431, 2010.

Kylander, M. E., Ampel, L., Wohlfarth, B. and Veres, D.: High-resolution X-ray fluorescence core scanning analysis of Les

15 Echets (France) sedimentary sequence: new insights from chemical proxies, J. Quat. Sci., 26(1), 109-117, doi:10.1002/jqs.1438, 2011.

Landmann, G., Reimer, A. and Kempe, S.: Climatically induced lake level changes at Lake Van, Turkey, during the Pleistocene/Holocene Transition, Glob. Biogeochem. Cycles, 10(4), 797-808, doi:10.1029/96GB02347, 1996a.

Landmann, G., Reimer, A., Lemcke, G. and Kempe, S.: Dating Late Glacial abrupt climate changes in the 14,570 yr long

20 continuous varve record of Lake Van, Turkey, Palaeogeogr. Palaeoclimatol. Palaeoecol., 122(1-4), 107-118, doi:10.1016/0031-0182(95)00101-8, 1996b.

Lauterbach, S., Witt, R., Plessen, B., Dulski, P., Prasad, S., Mingram, J., Gleixner, G., Hettler-Riedel, S., Stebich, M., Schnetger, B., Schwalb, A. and Schwarz, A.: Climatic imprint of the mid-latitude Westerlies in the Central Tian Shan of Kyrgyzstan and teleconnections to North Atlantic climate variability during the last 6000 years, The Holocene, (24), 970-

25 984, doi:10.1177/0959683614534741, 2014.

Lei, Y., Tian, L., Bird, B. W., Hou, J., Ding, L., Oimahmadov, I. and Gadoev, M.: A 2540-year record of moisture variations derived from lacustrine sediment (Sasikul Lake) on the Pamir Plateau, The Holocene, 24(7), 761-770, doi:10.1177/0959683614530443, 2014.

Lister, G. S., Kelts, K., Zao, C. K., Yu, J.-Q. and Niessen, F.: Paleoenvironments of Salt Lakes Lake Qinghai, China: closed-

30 basin like levels and the oxygen isotope record for ostracoda since the latest Pleistocene, Palaeogeogr. Palaeoclimatol. Palaeoecol., 84(1), 141-162, doi:10.1016/0031-0182(91)90041-O, 1991.

Liu, X., Herzschuh, U., Wang, Y., Kuhn, G. and Yu, Z.: Glacier fluctuations of Muztagh Ata and temperature changes during the late Holocene in westernmost Tibetan Plateau, based on glaciolacustrine sediment records, Geophys. Res. Lett., 41(17), 2014GL060444, doi:10.1002/2014GL060444, 2014.

35 Loader, N. J., Helle, G., Los, S. O., Lehmkuhl, F. and Schleser, G. H.: Twentieth-century summer temperature variability in the southern Altai Mountains: A carbon and oxygen isotope study of tree-rings, The Holocene, (20), 1149-1156, doi:10.1177/0959683610369507, 2010. 
Clim. Past Discuss., doi:10.5194/cp-2016-34, 2016

Manuscript under review for journal Clim. Past

Published: 7 April 2016

(c) Author(s) 2016. CC-BY 3.0 License.

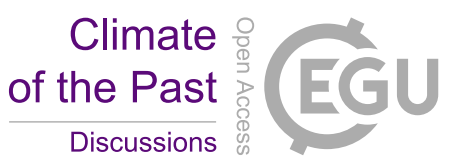

Marcott, S. A., Shakun, J. D., Clark, P. U. and Mix, A. C.: A Reconstruction of Regional and Global Temperature for the Past 11,300 Years, Science, 339(6124), 1198-1201, doi:10.1126/science.1228026, 2013.

Mayer, L. M., Macko, S. A., Mook, W. H. and Murray, S.: The distribution of bromine in coastal sediments and its use as a source indicator for organic matter, Org. Geochem., 3(1), 37-42, doi:10.1016/0146-6380(81)90011-5, 1981.

5 Melack, J. M.: Large, deep salt lakes: a comparative limnological analysis, Hydrobiologia, 105(1), 223-230, doi:10.1007/BF00025190, 1983.

Meyers, P. A. and Lallier-vergés, E.: Lacustrine Sedimentary Organic Matter Records of Late Quaternary Paleoclimates, J. Paleolimnol., 21(3), 345-372, doi:10.1023/A:1008073732192, 1999.

Meyers, P. A. and Teranes, J. L.: Sediment Organic Matter, in Tracking Environmental Change Using Lake Sediments, vol.

10 Physical and Geochemical Methods, edited by W. M. Last and J. P. Smol, pp. 239-269, Kluwer Academic Publishers, Dordrecht. [online] Available from: http://link.springer.com/chapter/10.1007/0-306-47670-3_9 (Accessed 19 October 2015), 2002.

Mischke, S. and Zhang, C.: Ostracod distribution in Ulungur Lake (Xinjiang, China) and a reassessed Holocene record, Ecol. Res., 26(1), 133-145, doi:10.1007/s11284-010-0768-1, 2010.

15 Mischke, S., Rajabov, I., Mustaeva, N., Zhang, C., Herzschuh, U., Boomer, I., Brown, E. T., Andersen, N., Myrbo, A., Ito, E. and Schudack, M. E.: Modern hydrology and late Holocene history of Lake Karakul, eastern Pamirs (Tajikistan): A reconnaissance study, Palaeogeogr. Palaeoclimatol. Palaeoecol., 289(1-4), 10-24, doi:10.1016/j.palaeo.2010.02.004, 2010a.

Mischke, S., Aichner, B., Diekmann, B., Herzschuh, U., Plessen, B., Wünnemann, B. and Zhang, C.: Ostracods and stable isotopes of a late glacial and Holocene lake record from the NE Tibetan Plateau, Chem. Geol., 276(1-2), 95-103, doi:10.1016/j.chemgeo.2010.06.003, 2010b.

Murari, M. K., Owen, L. A., Dortch, J. M., Caffee, M. W., Dietsch, C., Fuchs, M., Haneberg, W. C., Sharma, M. C. and Townsend-Small, A.: Timing and climatic drivers for glaciation across monsoon-influenced regions of the HimalayanTibetan orogen, Quat. Sci. Rev., 88, 159-182, doi:10.1016/j.quascirev.2014.01.013, 2014.

Nöth, L., Ficker, H. V. and Rickmers, W. R. (Eds. .: Geologische Untersuchungen im Nordwestlichen Pamir-Gebiet und Mittleren Trans-Alai, Reimer-Vohsen, Berlin., 1932.

Opitz, S., Wünnemann, B., Aichner, B., Dietze, E., Hartmann, K., Herzschuh, U., IJmker, J., Lehmkuhl, F., Li, S., Mischke, S., Plotzki, A., Stauch, G. and Diekmann, B.: Late Glacial and Holocene development of Lake Donggi Cona, north-eastern Tibetan Plateau, inferred from sedimentological analysis, Palaeogeogr. Palaeoclimatol. Palaeoecol., 337-338, 159-176, doi:10.1016/j.palaeo.2012.04.013, 2012.

30 Owen, L. A. and Dortch, J. M.: Nature and timing of Quaternary glaciation in the Himalayan-Tibetan orogen, Quat. Sci. Rev., 88, 14-54, doi:10.1016/j.quascirev.2013.11.016, 2014.

Pachauri, R. K., Allen, M. R., Barros, V. R., Broome, J., Cramer, W., Christ, R., Church, J. A., Clarke, L., Dahe, Q., Dasgupta, P., Dubash, N. K., Edenhofer, O., Elgizouli, I., Field, C. B., Forster, P., Friedlingstein, P., Fuglestvedt, J., GomezEcheverri, L., Hallegatte, S., Hegerl, G., Howden, M., Jiang, K., Jimenez Cisneroz, B., Kattsov, V., Lee, H., Mach, K. J.,

35 Marotzke, J., Mastrandrea, M. D., Meyer, L., Minx, J., Mulugetta, Y., O’Brien, K., Oppenheimer, M., Pereira, J. J., PichsMadruga, R., Plattner, G.-K., Pörtner, H.-O., Power, S. B., Preston, B., Ravindranath, N. H., Reisinger, A., Riahi, K., Rusticucci, M., Scholes, R., Seyboth, K., Sokona, Y., Stavins, R., Stocker, T. F., Tschakert, P., van Vuuren, D. and van Ypserle, J.-P.: Climate Change 2014: Synthesis Report. Contribution of Working Groups I, II and III to the Fifth Assessment 
Clim. Past Discuss., doi:10.5194/cp-2016-34, 2016

Manuscript under review for journal Clim. Past

Published: 7 April 2016

(c) Author(s) 2016. CC-BY 3.0 License.

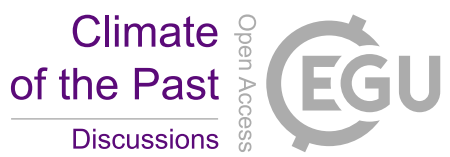

Report of the Intergovernmental Panel on Climate Change, edited by R. K. Pachauri and L. Meyer, IPCC, Geneva, Switzerland. [online] Available from: http://epic.awi.de/37530/ (Accessed 4 January 2016), 2014.

Pielke, R. A., Avissar, R., Raupach, M., Dolman, A. J., Zeng, X., Denning, A. S. and others: Interactions between the atmosphere and terrestrial ecosystems: influence on weather and climate, Glob. Change Biol., 4(5), 461-475, 1998.

5 Rades, E. F., Tsukamoto, S., Frechen, M., Xu, Q. and Ding, L.: A lake-level chronology based on feldspar luminescence dating of beach ridges at Tangra Yum Co (southern Tibet), Quat. Res., 83(3), 469-478, 2015.

Ramaswamy, C.: Breaks in the Indian summer monsoon as a phenomenon of interaction between the easterly and the subtropical westerly jet streams1, Tellus, 14(3), 337-349, doi:10.1111/j.2153-3490.1962.tb01346.x, 1962.

R Core Team: R: A language and environment for statistical computing, R Foundation for Statistical Computing, Vienna,

Austria. [online] Available from: https://cran.r-project.org, 2012.

Reimer, A., Landmann, G. and Kempe, S.: Lake Van, Eastern Anatolia, Hydrochemistry and History, Aquat. Geochem., 15(1-2), 195-222, doi:10.1007/s10498-008-9049-9, 2008.

Reimer, P.: IntCal13 and Marine13 Radiocarbon Age Calibration Curves 0-50,000 Years cal BP, Radiocarbon, 55(4), 18691887, doi:10.2458/azu_js_rc.55.16947, 2013.

15 Ricketts, R. D., Johnson, T. C., Brown, E. T., Rasmussen, K. A. and Romanovsky, V. V.: The Holocene paleolimnology of Lake Issyk-Kul, Kyrgyzstan: trace element and stable isotope composition of ostracodes, Palaeogeogr. Palaeoclimatol. Palaeoecol., 176(1-4), 207-227, doi:10.1016/S0031-0182(01)00339-X, 2001.

Robinson, S. A., Black, S., Sellwood, B. W. and Valdes, P. J.: A review of palaeoclimates and palaeoenvironments in the Levant and Eastern Mediterranean from 25,000 to 5000 years BP: setting the environmental background for the evolution of human civilisation, Quat. Sci. Rev., 25(13-14), 1517-1541, doi:10.1016/j.quascirev.2006.02.006, 2006.

Romanovsky, V. V.: Water Level Variations and Water Balance of Lake Issyk-Kul, in Lake Issyk-Kul: Its Natural Environment, edited by J. Klerkx and B. Imanackunov, pp. 45-57, Springer Netherlands. [online] Available from: http://link.springer.com/chapter/10.1007/978-94-010-0491-6_4 (Accessed 28 September 2015), 2002.

Sato, T.: Influences of subtropical jet and Tibetan Plateau on precipitation pattern in Asia: Insights from regional climate modeling, Quat. Int., 194(1-2), 148-158, doi:10.1016/j.quaint.2008.07.008, 2009.

Seong, Y. B., Owen, L. A., Yi, C. and Finkel, R. C.: Quaternary glaciation of Muztag Ata and Kongur Shan: Evidence for glacier response to rapid climate changes throughout the Late Glacial and Holocene in westernmost Tibet, Geol. Soc. Am. Bull., 121(3-4), 348-365, doi:10.1130/B26339.1, 2009.

Sorrel, P., Oberhänsli, H., Boroffka, N., Nourgaliev, D., Dulski, P. and Röhl, U.: Control of wind strength and frequency in the Aral Sea basin during the late Holocene, Quat. Res., 67(3), 371-382, doi:10.1016/j.yqres.2006.12.003, 2007.

Stein, M.: The Evolution of Neogene-Quaternary Water-Bodies in the Dead Sea Rift Valley, in Dead Sea Transform Fault System: Reviews, edited by Z. Garfunkel, Z. Ben-Avraham, and E. Kagan, pp. 279-316, Springer Netherlands. [online] Available from: http://link.springer.com/chapter/10.1007/978-94-017-8872-4_10 (Accessed 29 February 2016), 2014.

Strecker, M. R., Frisch, W., Hamburger, M. W., Ratschbacher, L., Semiletkin, S., Zamoruyev, A. and Sturchio, N.:

35 Quaternary deformation in the Eastern Pamirs, Tadzhikistan and Kyrgyzstan, Tectonics, 14(5), 1061-1079, doi:10.1029/95TC00927, 1995. 
Clim. Past Discuss., doi:10.5194/cp-2016-34, 2016

Manuscript under review for journal Clim. Past

Published: 7 April 2016

(c) Author(s) 2016. CC-BY 3.0 License.

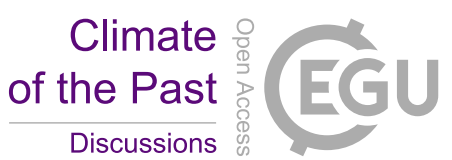

Taft, L., Mischke, S., Wiechert, U., Leipe, C., Rajabov, I. and Riedel, F.: Sclerochronological oxygen and carbon isotope ratios in Radix (Gastropoda) shells indicate changes of glacial meltwater flux and temperature since 4,200 cal yr BP at Lake Karakul, eastern Pamirs (Tajikistan), J. Paleolimnol., 52(1-2), 27-41, doi:10.1007/s10933-014-9776-4, 2014.

Talbot, M. R.: A review of the palaeohydrological interpretation of carbon and oxygen isotopic ratios in primary lacustrine carbonates, Chem. Geol. Isot. Geosci. Sect., 80(4), 261-279, doi:10.1016/0168-9622(90)90009-2, 1990.

Tjallingii, R., Röhl, U., Kölling, M. and Bickert, T.: Influence of the water content on X-ray fluorescence core-scanning measurements in soft marine sediments, Geochem. Geophys. Geosystems, 8(2) [online] Available from: http://onlinelibrary.wiley.com/doi/10.1029/2006GC001393/full (Accessed 10 February 2016), 2007.

Tsoar, H. and Pye, K.: Dust transport and the question of desert loess formation, Sedimentology, 34(1), 139-153, doi:10.1111/j.1365-3091.1987.tb00566.x, 1987.

Van Campo, E. and Gasse, F.: Pollen- and Diatom-Inferred Climatic and Hydrological Changes in Sumxi Co Basin (Western Tibet) since 13,000 yr B.P., Quat. Res., 39(3), 300-313, doi:10.1006/qres.1993.1037, 1993.

Van Campo, E., Cour, P. and Sixuan, H.: Holocene environmental changes in Bangong Co basin (Western Tibet). Part 2: The pollen record, Environ. Chang. Tibet. Plateau Surround. Areas, 120(1-2), 49-63, doi:10.1016/0031-0182(95)00033-X, 1996.

Vandenberghe, J.: Grain size of fine-grained windblown sediment: A powerful proxy for process identification, Earth-Sci. Rev., 121, 18-30, 2013.

Vandenberghe, J., Renssen, H., van Huissteden, K., Nugteren, G., Konert, M., Lu, H., Dodonov, A. and Buylaert, J.-P.: Penetration of Atlantic westerly winds into Central and East Asia, Quat. Sci. Rev., 25(17-18), 2380-2389, doi:10.1016/j.quascirev.2006.02.017, 2006.

Wang, R., Zhang, Y., Wünnemann, B., Biskaborn, B. K., Yin, H., Xia, F., Zhou, L. and Diekmann, B.: Linkages between Quaternary climate change and sedimentary processes in Hala Lake, northern Tibetan Plateau, China, J. Asian Earth Sci., 107, 140-150, doi:10.1016/j.jseaes.2015.04.008, 2015.

Wang, Y., Liu, X. and Herzschuh, U.: Asynchronous evolution of the Indian and East Asian Summer Monsoon indicated by

Holocene moisture patterns in monsoonal central Asia, Earth-Sci. Rev., 103(3-4), 135-153, doi:10.1016/j.earscirev.2010.09.004, 2010.

Wang, Y., Herzschuh, U., Shumilovskikh, L. S., Mischke, S., Birks, H. J. B., Wischnewski, J., Böhner, J., Schlütz, F., Lehmkuhl, F., Diekmann, B., Wünnemann, B. and Zhang, C.: Quantitative reconstruction of precipitation changes on the NE Tibetan Plateau since the Last Glacial Maximum - extending the concept of pollen source area to pollen-based climate reconstructions from large lakes, Clim. Past, 10(1), 21-39, doi:10.5194/cp-10-21-2014, 2014.

Wang, Y. J., Cheng, H., Edwards, R. L., An, Z. S., Wu, J. Y., Shen, C.-C. and Dorale, J. A.: A High-Resolution AbsoluteDated Late Pleistocene Monsoon Record from Hulu Cave, China, Science, 294(5550), 2345-2348, doi:10.1126/science.1064618, 2001.

Weltje, G. J.: End-member modelling of compositional data: Numerical-statistical algorithms for solving the explicit mixing problem, Math. Geol., 29(4), 503-549, doi:10.1007/BF02775085, 1997.

Weltje, G. J. and Tjallingii, R.: Calibration of XRF core scanners for quantitative geochemical logging of sediment cores: Theory and application, Earth Planet. Sci. Lett., 274(3-4), 423-438, doi:10.1016/j.eps1.2008.07.054, 2008. 
Clim. Past Discuss., doi:10.5194/cp-2016-34, 2016

Manuscript under review for journal Clim. Past

Published: 7 April 2016

(c) Author(s) 2016. CC-BY 3.0 License.

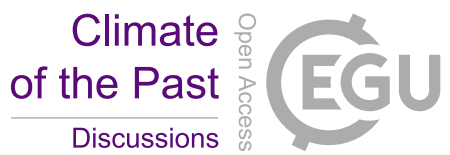

Wick, L., Lemcke, G. and Sturm, M.: Evidence of Lateglacial and Holocene climatic change and human impact in eastern Anatolia: high-resolution pollen, charcoal, isotopic and geochemical records from the laminated sediments of Lake Van, Turkey, The Holocene, 13(5), 665-675, doi:10.1191/0959683603hl653rp, 2003.

Williamson, C. E., Dodds, W., Kratz, T. K. and Palmer, M. A.: Lakes and streams as sentinels of environmental change in terrestrial and atmospheric processes, Front. Ecol. Environ., 6(5), 247-254, doi:10.1890/070140, 2008.

Wischnewski, J., Mischke, S., Wang, Y. and Herzschuh, U.: Reconstructing climate variability on the northeastern Tibetan Plateau since the last Lateglacial - a multi-proxy, dual-site approach comparing terrestrial and aquatic signals, Quat. Sci. Rev., 30(1-2), 82-97, doi:10.1016/j.quascirev.2010.10.001, 2011.

Wu, G., Yao, T., Xu, B., Li, Z., Tian, L., Duan, K. and Wen, L.: Grain size record of microparticles in the Muztagata ice core, Sci. China Ser. D, 49(1), 10-17, doi:10.1007/s11430-004-5093-5, 2006.

Wünnemann, B., Mischke, S. and Chen, F.: A Holocene sedimentary record from Bosten Lake, China, Palaeogeogr. Palaeoclimatol. Palaeoecol., 234(2-4), 223-238, doi:10.1016/j.palaeo.2005.10.016, 2006.

Wünnemann, B., Wagner, J., Zhang, Y., Yan, D., Wang, R., Shen, Y., Fang, X. and Zhang, J.: Implications of diverse sedimentation patterns in Hala Lake, Qinghai Province, China for reconstructing Late Quaternary climate, J. Paleolimnol., 48(4), 725-749, doi:10.1007/s10933-012-9641-2, 2012.

Zech, R., Abramowski, U., Glaser, B., Sosin, P., Kubik, P. W. and Zech, W.: Late Quaternary glacial and climate history of the Pamir Mountains derived from cosmogenic 10Be exposure ages, Quat. Res., 64(2), 212-220, doi:10.1016/j.yqres.2005.06.002, 2005.

Zhang, C. and Mischke, S.: A Lateglacial and Holocene lake record from the Nianbaoyeze Mountains and inferences of lake,

20 glacier and climate evolution on the eastern Tibetan Plateau, Quat. Sci. Rev., 28(19-20), 1970-1983, doi:10.1016/j.quascirev.2009.03.007, 2009.

Zhao, Y., Yu, Z. and Chen, F.: Spatial and temporal patterns of Holocene vegetation and climate changes in arid and semiarid China, Quat. Int., 194(1-2), 6-18, doi:10.1016/j.quaint.2007.12.002, 2009.

Zhu, L., Lü, X., Wang, J., Peng, P., Kasper, T., Daut, G., Haberzettl, T., Frenzel, P., Li, Q., Yang, R., Schwalb, A. and

25 Mäusbacher, R.: Climate change on the Tibetan Plateau in response to shifting atmospheric circulation since the LGM, Sci. Rep., 5, 13318, doi:10.1038/srep13318, 2015.

Ziegler, M., Jilbert, T., de Lange, G. J., Lourens, L. J. and Reichart, G.-J.: Bromine counts from XRF scanning as an estimate of the marine organic carbon content of sediment cores, Geochem. Geophys. Geosystems, 9(5) [online] Available from: http://onlinelibrary.wiley.com/doi/10.1029/2007GC001932/pdf (Accessed 20 October 2015), 2008. 
Clim. Past Discuss., doi:10.5194/cp-2016-34, 2016

Manuscript under review for journal Clim. Past

Published: 7 April 2016

(c) Author(s) 2016. CC-BY 3.0 License.

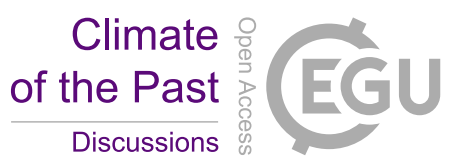

(c) (1)

Table 1. Radiocarbon dates from dated materials, including a living charophyte. Ages have been corrected for the lake reservoir effect of 1368 years and were calculated in BACON (Blaauw and Christen, 2011) (Fig.2).

\begin{tabular}{|c|c|c|c|c|c|}
\hline Sample No & Depth $(\mathrm{cm})$ & Material & ${ }^{14} \mathrm{C}$ age (yr BP) & $\begin{array}{l}\text { Calibrated and } \\
\text { reservoir } \\
\text { corrected age (yr } \\
\text { BP) }\end{array}$ & Laboratory ID \\
\hline KK12-10 & 0 & insitu plant April 2012 & $950 \pm 25 \mathrm{BP}$ & 0 & Poz-53829 \\
\hline KK12-1 01 & $0-1$ & Plant remains & $1615 \pm 30 \mathrm{BP}$ & n.d. & Poz-53820 \\
\hline KK12-1 115 & $114-115$ & Plant remains & $2755 \pm 35 \mathrm{BP}$ & $1181-1419$ & Poz-56643 \\
\hline KK12-1 250 & $249-250$ & Plant remains & $4175 \pm 30 \mathrm{BP}$ & $2796-3112$ & Poz-53822 \\
\hline KK12-1 370 & $371-372$ & Plant remains & $5340 \pm 35 \mathrm{BP}$ & $4332-4827$ & Poz-56644 \\
\hline KK12-1 468 & $469-470$ & Bulk sediment/TOC & $7530 \pm 40 \mathrm{BP}$ & $6841-7228$ & Poz-53823 \\
\hline KK12-1 538 & $559-560$ & Plant remains & $2430 \pm 30 \mathrm{BP}$ & 10313-12057 & Poz-53826 \\
\hline KK12-1 560 & $581-582$ & Bulk sediment/TOC & $11900 \pm 60 \mathrm{BP}$ & $11797-12637$ & Poz-56556 \\
\hline KK12-1 625 & $646-647$ & Bulk sediment/TOC & $13550 \pm 60 \mathrm{BP}$ & 13849-15092 & Poz-56555 \\
\hline KK12-1 689 & $737-738$ & Moss & $18790 \pm 100 \mathrm{BP}$ & $17851-20954$ & Poz-53827 \\
\hline KK12-1 775 & $823-824$ & Plant remains & $21400 \pm 110 \mathrm{BP}$ & 21109-23307 & Poz-56648 \\
\hline KK12-1 851 & $899-900$ & Plant remains & $21280 \pm 100 \mathrm{BP}$ & $23523-24520$ & Poz-53828 \\
\hline KK12-1 935 & $1002-1003$ & Plant Remains & $23230 \pm 130 \mathrm{BP}$ & $25834-27023$ & Poz-56649 \\
\hline KK12-1 1019 & $1086-1087$ & Bulk sediment/TOC & $27300 \pm 200 \mathrm{BP}$ & $27578-29773$ & Poz-53821 \\
\hline
\end{tabular}


Clim. Past Discuss., doi:10.5194/cp-2016-34, 2016

Manuscript under review for journal Clim. Past

Published: 7 April 2016

(c) Author(s) 2016. CC-BY 3.0 License.

\section{Climate of the Past \\ Discussions}

(c) (1)

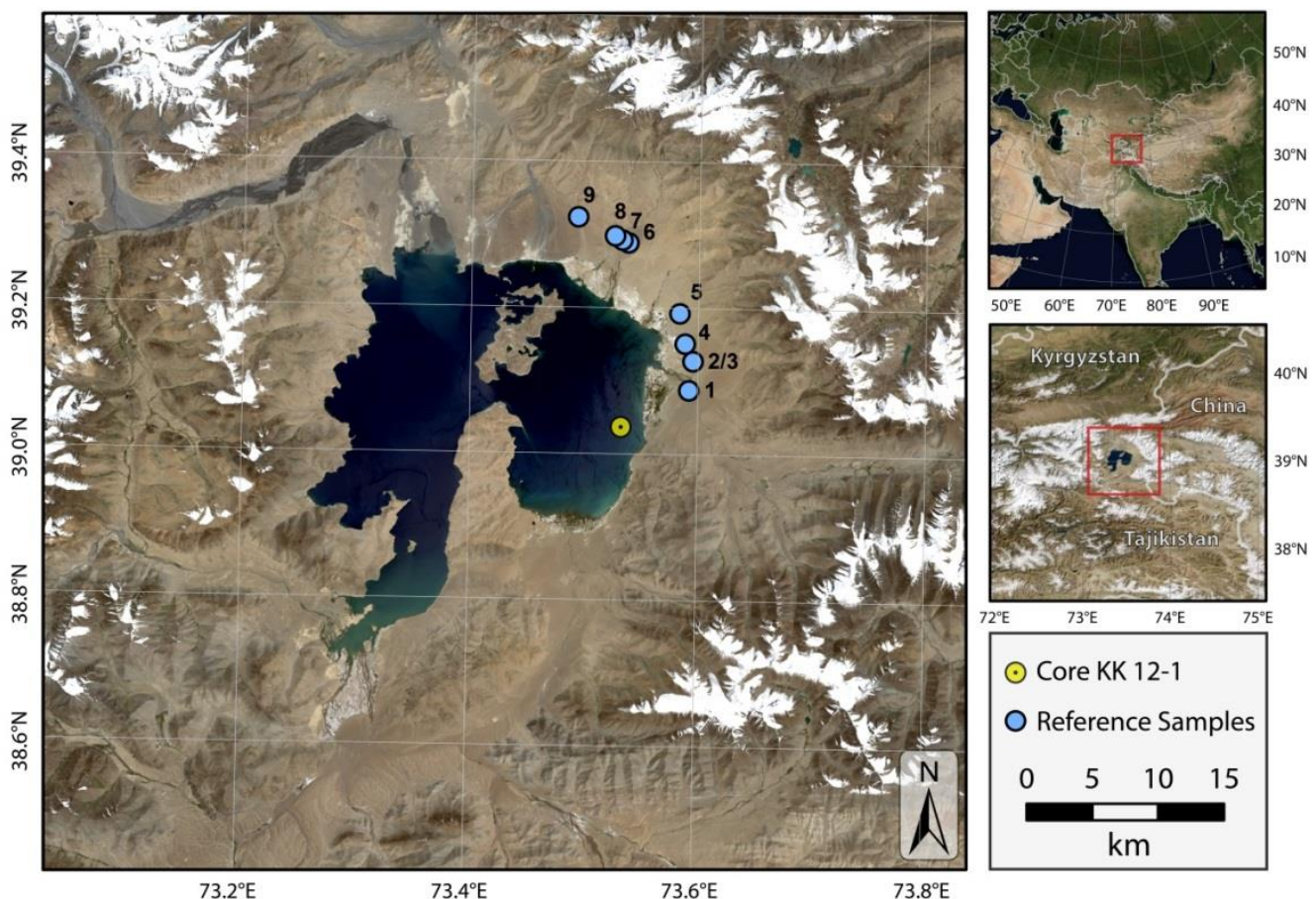

Figure 1: Lake Karakul in the Pamir Mountains, Tajikistan, in arid Central Asia.

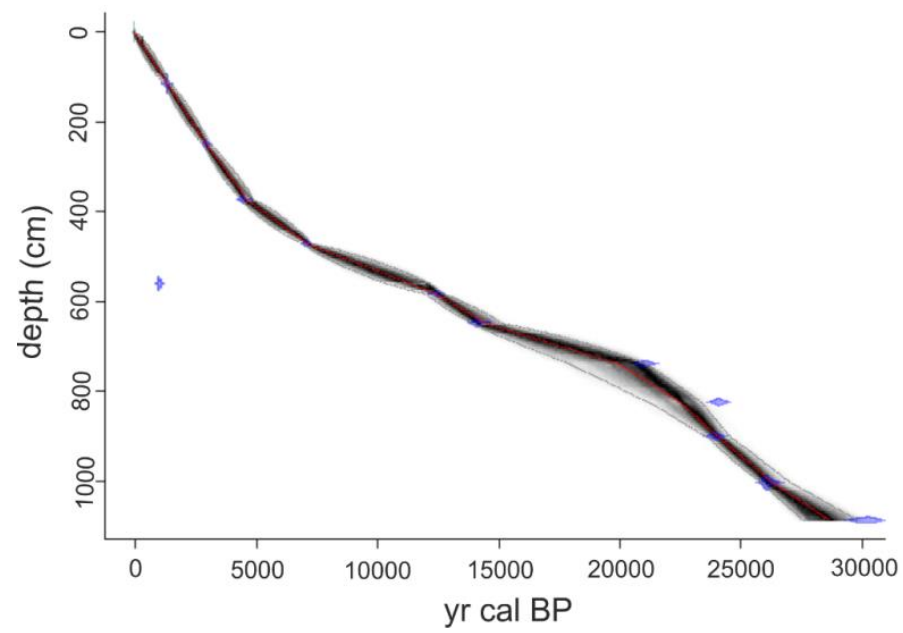

Figure 2: Age-depth model for core KK12-1 constructed in Bacon (Blaauw and Christen, 2011) with 12 radiocarbon dates and a 5 calculated reservoir effect of $1368 \mathrm{yr}$. 
Clim. Past Discuss., doi:10.5194/cp-2016-34, 2016

Manuscript under review for journal Clim. Past

Published: 7 April 2016

(c) Author(s) 2016. CC-BY 3.0 License.

\section{(c) (1)}

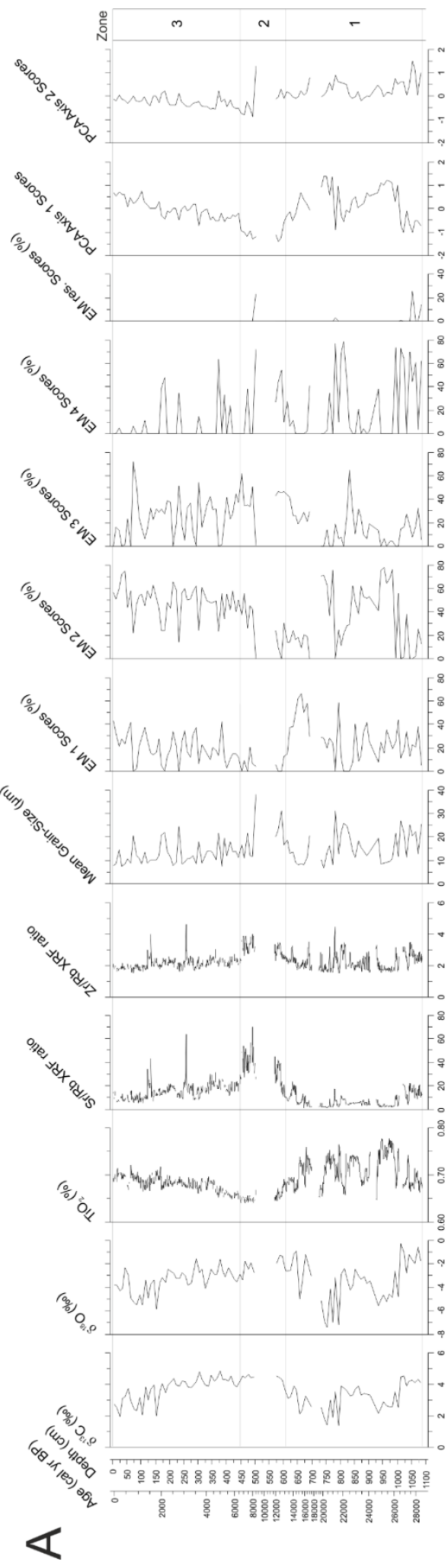

Climate of the Past

Discussions 
Clim. Past Discuss., doi:10.5194/cp-2016-34, 2016

Manuscript under review for journal Clim. Past

Published: 7 April 2016

(c) Author(s) 2016. CC-BY 3.0 License.
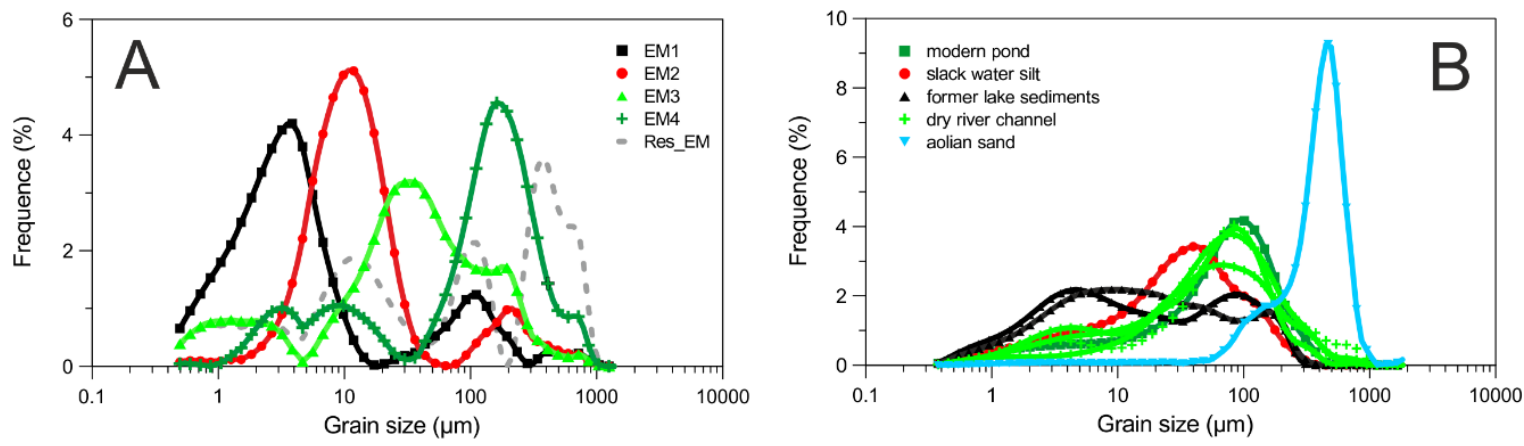

10 Figure 4: End-member modelling for core KK12-1. A - Grain-size distribution of the nine reference samples in the vicinity of Lake Karakul, B - Loading of grain size based end-member modelling of Lake Karakul.
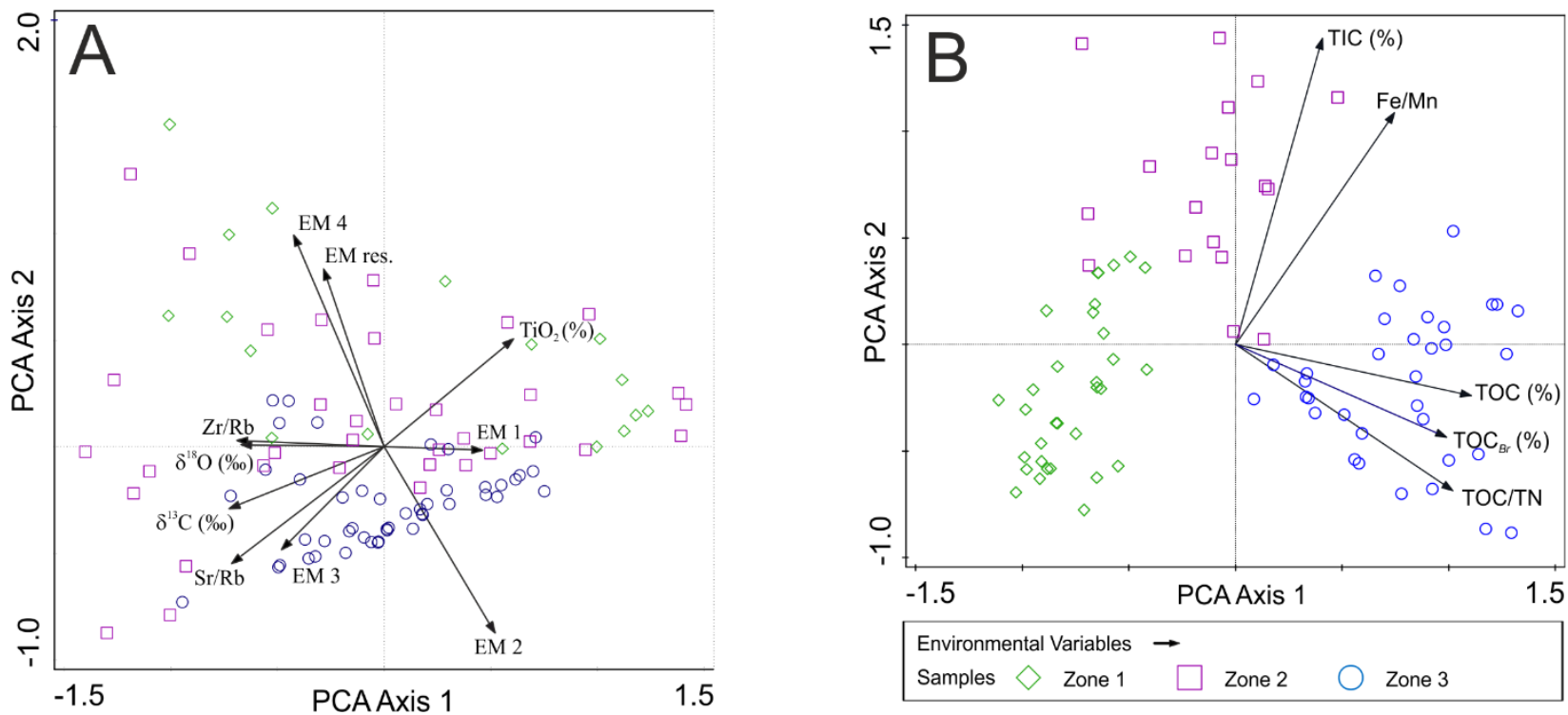

15

Figure 5: Biplot for principal component analyses (PCA) of geochemical and sedimentological parameters for core KK12-1. A - for external parameters zone 1: 28.6 to $13.3 \mathrm{cal} \mathrm{kyr}$ BP, zone 2: 13.3 to $6.6 \mathrm{cal} \mathrm{kyr}$ BP, zone 3: 6.6 cal kyr BP to present; B - for interal parameters zone 1: 28.6 to 18.4 cal kyr BP, zone 2: 18.3 to 6.7 cal kyr BP, zone 3: 6.7 cal kyr BP to present. 